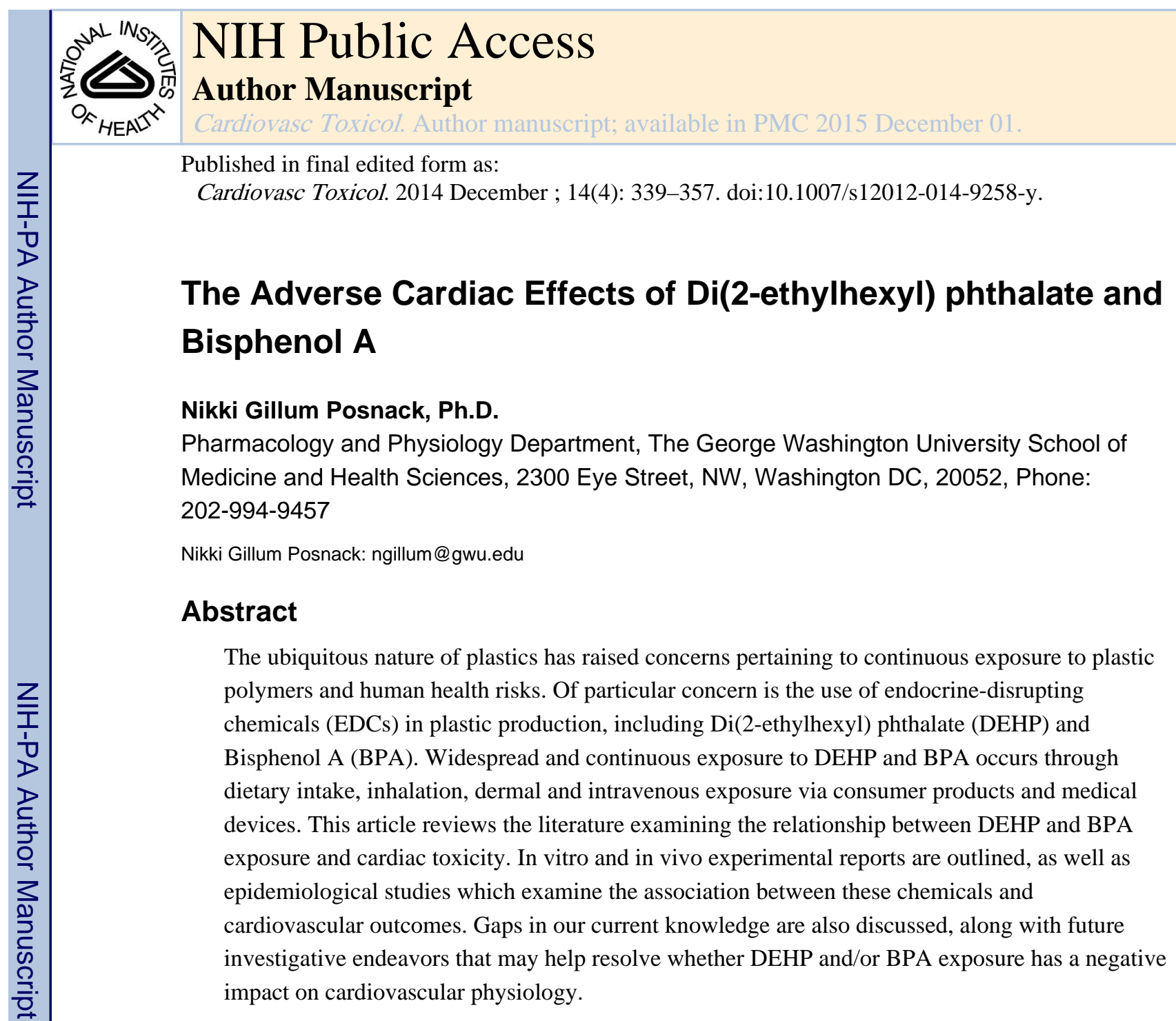

\title{
Introduction
}

The incorporation of plasticizers and other additives has promoted versatility in plastic materials which, when combined with the low cost of production, has led to mass plastic production - exceeding 300 million tons in $2010^{1}$. Plastics are indispensable materials; yet, the ubiquitous use of plastic products has raised valid concerns pertaining to continuous exposure and human health risks. Health concerns primarily arise from the building blocks of plastics (i.e., BPA) and plastic additives (i.e., DEHP), both of which have endocrinedisrupting properties ${ }^{1,2}$. Endocrine disrupting chemicals are exogenous compounds that interfere with hormone homeostasis ${ }^{3}$. These chemicals initiate downstream effects through interaction with nuclear receptors, hormone receptors, orphan receptors, or by modifying enzymatic pathways involved in steroid biosynthesis or metabolism ${ }^{3}$. Despite the increasing popularity of BPA-free and phthalate-free plastics, these compounds are found in many consumer products, including food and beverage containers, electronics, and medical devices $^{4-7}$. As a result, exposure to these EDCs has become virtually continuous and essentially unavoidable, a fact that is highlighted by numerous human biomonitoring studies $^{8-13}$. 
Accumulating evidence suggests a link between EDC exposure and adverse human health outcomes, including cardiovascular conditions. Epidemiological studies have shown positive correlations between EDC exposure and coronary artery disease, hypertension, atherosclerosis, and myocardial infarction ${ }^{14-21}$. These associations are even more worrisome for patient populations who are more susceptible to cardiac disturbances, including neonates and infants, the elderly, and those with pre-existing heart conditions. Since increased EDC exposure is only associated with these disorders, and has not been recognized as causative, their potential toxicity is hotly debated. As a recent example, the appropriateness of using cross-sectional datasets to identify associations between environmental chemical exposure and complex diseases has been questioned by at least one group ${ }^{22}$. However, the financial support of this study by the chemical industry (Polycarbonate/BPA global work) adds further complexity to this debate. Consequently, there is a need on behalf of the public, scientific, medical and regulatory communities to resolve this debate by directly assessing the impact of EDCs on cardiac physiology and to identify the risks to both general and vulnerable patient populations.

\section{Di-2(ethylhexyl)phthalate (DEHP)}

\section{Exposure}

DEHP is a commonly used phthalate ester plasticizer that is used to impart flexibility and elasticity to polyvinyl chloride (PVC) products. Human exposure to DEHP occurs through contact with food packaging, toys, personal care products and medical devices. Exposure routes include ingestion, dermal uptake, inhalation, and direct release into the body from medical products (subcutaneous, intravenous). In addition to exposure via consumer products, DEHP is also the most widely used phthalate in FDA-approved medical devices and intravenous bags, including: bags containing blood, plasma, intravenous fluids, and total parenteral nutrition, tubing associated with their administration, nasogastric tubes, enteral feeding tubes, umbilical catheters, extracorporeal membrane oxygenation (ECMO) circuit tubing, hemodialysis tubing, respiratory masks, endotracheal tubes, and examination gloves. DEHP can contribute up to $40 \%$ by weight of intravenous bags and up to $80 \%$ weight in medical tubing ${ }^{1,23}$.

DEHP's use in medical products is of particular concern, as exposure to DEHP increases dramatically in patients undergoing multiple medical interventions, such as bypass, hemodialysis circuits or long-term use of tubing in intensive care units ${ }^{24}$. This is because DEHP is not covalently bound to the PVC polymer and is hydrophobic, making it highly susceptible to leaching when in contact with blood, plasma, total parental nutrition solution, formulation aids used to solubilize medications, and other lipophilic fluids ${ }^{24}$. The rate at which DEHP migrates from the plastic product is dependent upon the storage conditions (temperature, volume of solution, contact time, and extent of shaking or flow rate of the fluid) and the lipophilicity of the fluid ${ }^{25,26}$. DEHP leaching has been reported to vary between $0.25-0.40 \mathrm{mg} / 100 \mathrm{~mL} /$ day for whole blood stored more than 21 days at $4^{\circ} \mathrm{C}$, to 6 $\mathrm{mg} / \mathrm{unit}$ of platelet concentrate stored at room temperature $25,27,28$. Furthermore, DEHP tubing has been shown to disintegrate with time, with one study measuring 6-12\% less 
weight after product usage ${ }^{29}$, and another study reporting large particle debris from tubing degradation ${ }^{30}$. Of interest, both studies attributed medical complications to these findings.

DEHP exposure levels (Table 1) range depending on lifestyle factors ${ }^{9,20,31-41}$ and medical device use $8,13,25,42-51$, with high concentrations detected in blood samples from patients undergoing medical interventions $(20-30 \mu \mathrm{g} / \mathrm{mL} \text { range })^{47-51}$. Moreover, clinical studies frequently report DEHP concentrations in serum samples, which may actually underreport total exposure, as, a significant amount of DEHP binds to the membrane and cytosolic fraction of red blood cells ${ }^{48}$. Even higher exposure levels have been routinely detected in blood storage bags $(150-300 \mu \mathrm{g} / \mathrm{mL} \text { range })^{25,47,48,52}$. For simplicity, we perceive 300 $\mu \mathrm{g} / \mathrm{mL}$ as a threshold concentration for experimental toxicology studies assessing DEHP's effects on cardiac physiology.

\section{Adverse health effects}

A number of studies have reported toxic effects of DEHP and its metabolites (reviewed by Halden ${ }^{1}$ and Carlson ${ }^{53}$ ). Because of DEHP's endocrine-disrupting properties, most reports have concentrated on its risk of carcinogenicity, reproductive and developmental toxicities. Increased exposure to phthalates has been linked to adverse health outcomes in humans, including reduced anogenital distance in males, decreased sperm count, testicular dysfunction, early puberty in girls (a risk factor for breast cancer), increased waist circumference, insulin resistance, shorter pregnancy duration and low birth weight ${ }^{33,34,54-60}$. Indeed, the risk of testicular toxicity and the ensuing negative impact on fertility has warranted the use of DEHP-free tubing for premature boys ${ }^{61,62}$.

Phthalate leaching is a source of concern for children's health ${ }^{63}$, but even more so for patients in neonatal intensive care units (NICUs). There are two main reasons for this. First, critically ill neonates undergo multiple medical interventions over a prolonged period of time and these procedures frequently employ the use of stored fluids for transfusion and flexible tubing. Multiple medical interventions can result in high DEHP exposure, and it is estimated that NICU patients have a 26-fold higher phthalate exposure compared to the average child's environmental exposure ${ }^{8,64}$. The second reason is a curtailed glucuronidation pathway, which is not fully established in young children. Because glucuronidation facilitates urinary excretion of phthalates, and other xenobiotics, underdevelopment of this pathway increases the duration of exposure due to slow excretion ${ }^{65}$. Various regulatory agencies (Federal Drug Administration, Center for the Evaluation of Risks to Human Reproduction, Department of Human Health and Services, American Academy of Pediatrics) have concluded that critically ill neonates and other groups of patients exposed to DEHP over prolonged periods of time, can experience the adverse effects of phthalate esters ${ }^{24,66-68}$. As one example, use of DEHP-containing infusion systems for total parenteral nutrition was associated with a 5.6-fold increased risk of cholestasis among NICU infants and the incidence of hepatobiliary dysfunction declined from $50 \%$ to $13 \%$ after switching to DEHP-free tubing systems ${ }^{69}$. 


\section{Cardiac toxicity}

A. In vitro exposure studies-Forty years ago it was noted that DEHP [4 $\mu \mathrm{g} / \mathrm{mL}]$ caused cessation of contractile function in chick embryonic cardiomyocytes after acute exposure, and cell death ensued after 24 hours exposure 28 (Table 2). Notably, this concentration is well within the range of reported clinical exposure levels (Table 1). Our laboratory has also reported adverse effects on cardiomyocyte function, specifically, DEHP exposure $[1-50 \mu \mathrm{g} / \mathrm{mL}]$ resulted in a concentration-dependent decrease in conduction velocity beginning $24 \mathrm{hrs}$ after exposure and asynchronous cell beating after 3-days treatment ${ }^{70}$. This effect was predominately attributed to a loss of gap-junctional connexin- 43 protein expression. DEHP exposure $[250 \mu \mathrm{M}]$ has also been shown to modify cardiac electrical conduction in isolated perfused rat hearts, including a decrease in heart rate, and prolongation of PR and QT intervals ${ }^{71}$. Additionally, in situ studies have pointed to the potential cardiotoxic effects of Mono(2-ethylhexyl) phthalate (MEHP), the primary metabolite of DEHP. Specifically, Schulpen, et al. observed a significant decrease in human embryonic stem cell viability, along with a reduction in cardiac differentiation, following MEHP exposure ${ }^{72}$. And in situ studies have shown a concentration-dependent negative inotropic effect on human atrial trabeculae and a negative inotropic and chronotropic effect on isolated perfused rat hearts following MEHP exposure $[15-200 \mu \mathrm{g} / \mathrm{mL}]^{42,73,74}$.

B. In vivo exposure studies-Despite broad phthalate distribution throughout the body, including heart tissue ${ }^{75}$, only a few reports have examined the effect of DEHP or its metabolites on the intact cardiovascular system ${ }^{73,76-78}$. Conflicting results have been reported related to MEHP and DEHP's effect on blood pressure in adult ${ }^{73,78}$ and postnatal ${ }^{76}$ animals. Specifically, Martinez-Argulles, et al. reported a decrease in systolic and diastolic blood pressures in male offspring following in utero exposure to DEHP [300 mg/kg/day $]^{76}$. While Wei, et al. observed an increase in blood pressure in rat offspring following maternal exposure to DEHP from gestational day 0 - postnatal day $21[0.25-6.25 \mathrm{mg} / \mathrm{kg} / \mathrm{day}]^{77}$.

To the best of our knowledge, experimental studies examining the effects of in vivo DEHP exposure on cardiac electrical conduction, ventricular pressure or contractility have not been performed. Additional in vivo studies that take into account the indirect effects between organ systems and the impact of the metabolic system are necessary to fully discern whether the observed in vitro cardiac effects are relevant to living subjects.

C. Potential mechanisms-Functional assays and genomic expression analysis have hinted to the mechanisms underlying these observed cardiac effects. We have shown that microarray analysis on DEHP-treated neonatal rat cardiomyocytes has revealed global changes in mRNA expression, including genes associated with cell electrical activity, calcium handling, adhesion, microtubular transport, and metabolism ${ }^{79,80}$. The latter was investigated further, and DEHP was shown to upregulate genes associated with fatty acid transport, esterification, mitochondrial import and beta-oxidation ${ }^{80}$. The functional outcome was an increase in myocyte fatty acid-substrate utilization, oxygen consumption, mitochondrial mass, PPARa expression, extracellular acidosis and a decrease in glucose oxidation. These results are consistent with Aronson, et al., which showed that lactate concentration (acidosis) increased 400\% following DEHP-treatment of Langendorff- 
perfused rat hearts ${ }^{71}$. Similarly, lactational exposure to DEHP [100 mg/kg/day] has been shown to impair insulin signaling and glucose oxidation in cardiac tissue ${ }^{81}$. Moreover, Feige et al. observed reduced fat reserves and increased hepatic fatty acid oxidation in DEHPtreated mice compared with controls ${ }^{82}$. Of interest, this phenomenon was reversed when mice were genetically engineered to carry human PPARa, suggesting a species-specific effect. Notably, in our studies, treatment with a PPARa agonist only partially mimicked the effects of DEHP exposure ${ }^{80}$, suggesting that multiple mechanisms are likely at play. Even so, these studies suggest that DEHP exposure leads to a fuel switch that may be regulated at both the gene expression and posttranscriptional levels.

D. Epidemiological studies-Although experimental data suggests toxic effects of DEHP and MEHP on cardiac physiology, only three epidemiological studies have investigated this link in humans (Table 3). Specifically, higher urinary phthalate levels have been linked to increased blood pressure in adolescent populations ${ }^{20}$, and increased coronary risk in elderly populations ${ }^{17,83}$. The later found a significant association between higher MEHP urinary levels and LDL cholesterol levels ${ }^{83}$, but not blood pressure. This group also found a positive association between MEHP urinary levels and the echogenicity of vascular plaques ${ }^{17}$, which is an indicator of lipid infiltration and a predictor of future cardiovascular death. Prospective studies that comprehensively assess blood pressure changes, as well as inclusion of cardiac physiology indices (i.e., echocardiography, electrocardiography) would be beneficial to understanding the scope of DEHP's effects on the heart.

\section{Bisphenol-A (BPA)}

\section{Exposure}

BPA is a monomeric building block that is used in the production of polycarbonate plastics, polystyrene resins and dental sealants; it can also be used as an additive in PVC products. BPA is found in a vast amount of consumer products, including food and drink containers (including canned goods), water pipes, thermal paper and paper products (receipts, paper towels), toys, safety equipment, electronics, and medical devices ${ }^{4}$. Since some BPA monomers remain unbound during the manufacturing process, BPA can leach from these products under normal conditions of use ${ }^{4,84,85}$. Similarly to DEHP, the rate at which BPA migrates from the product is dependent upon storage conditions and frequency of use (i.e., temperature, prolonged contact with acidic/basic solutions) $)^{85}$. Due to its ubiquitous use, human biomonitoring studies have routinely detected BPA in $>90 \%$ of the population, including both children and adults $8,11,12,86$.

Similar to DEHP, BPA exposure (Table 4) ranges dramatically depending on lifestyle factors ${ }^{11,41,87-98}$, with industrial workers and NICU patients having overall higher urinary BPA levels $[4-8 \mu \mathrm{M} \text { range }]^{12,99,100}$. Human serum BPA levels are actively debated, with estimates ranging from $0.1-300 \mathrm{nM}$ for adults ${ }^{91,101-110}$. Individuals undergoing multiple medical interventions- such as NICU patients- most likely have even higher levels of BPA in the blood, although blood samples from these patients have not been analyzed. As previously mentioned, these patients have greater exposure levels due to multiple medical interventions and reduced glucuronidation activity, which increases total BPA exposure and time. For simplicity, we perceive $0.3 \mu \mathrm{M}$ (blood) and $8 \mu \mathrm{M}$ (urine) as a threshold 
concentration for experimental toxicology studies assessing BPA's effects on cardiac physiology.

\section{Adverse health effects}

Several studies have illuminated BPA's adverse effects (reviewed by Vandenberg ${ }^{111}$ ), particularly in relation to reproductive and developmental toxicities. Increased exposure to BPA has been associated with human health conditions, including cardiovascular disease, diabetes, reduced sperm quality, breast cancer, implantation failure, endometrial hyperplasia and polycystic ovarian syndrome ${ }^{14,15,18,112-115}$. Elevated BPA exposure in children is particularly worrisome ${ }^{116}$, since EDCs can have varying effects based on exposure time in relation to development. Indeed, lower BPA doses are necessary to induce alterations in estrogen-target organs when administered prenatally versus during adulthood ${ }^{117,118}$.

\section{Cardiac toxicity}

A. In vitro exposure studies-Recent experimental studies suggest that BPA may be arrhythmogenic, particularly in female subjects ${ }^{119-121}$. Acute BPA exposure [1 nM] increased the duration of sustained ventricular arrhythmias following ischemia-reperfusion injury in excised female hearts, and increased the incidence of spontaneous after contractions in isolated female rat ventricular cardiomyocytes ${ }^{119}$. These effects were exacerbated in the presence of estradiol and could not be replicated with male cardiac cells. BPA's pro-arrhythmic effects were abolished when samples were pretreated with an estrogen receptor (ER) antagonist, and also in an ER $\beta$ knockout model, suggesting mediation via ER signaling.

Our laboratory has also examined the effects of BPA on cardiac function using excised Langendorff-perfused hearts ${ }^{122}$. Although we did not observe arrhythmias in our studies, BPA exposure adversely affected cardiac electrical conduction in a concentration-dependent manner. Ex vivo exposure resulted in prolonged PR segment time and decreased epicardial conduction velocity $[0.1-100 \mu \mathrm{M}]$, prolonged action potential duration $[1-100 \mu \mathrm{M}]$ and delayed atrioventricular conduction $[10-100 \mu \mathrm{M}]$. Importantly, these effects were observed after acute exposure ( $\leq 15 \mathrm{~min}$ ), underscoring the potential detrimental effects of continuous BPA exposure. The highest BPA concentration used $[100 \mu \mathrm{M}]$ resulted in prolonged QRS intervals, dropped ventricular beats and eventually resulted in complete heart block. We observed slowing in sinus rate after exposure to high BPA concentrations; such a decrease in rate has also been observed by others, using both in vivo models ${ }^{123-125}$ and in vitro atrial preparations ${ }^{126}$. In the later, BPA $[10-100 \mu \mathrm{M}]$ exposure caused a decrease in atrial rate and force, which was attributed to involvement of the nitric oxide-guanylyl cyclase pathway. It is important to note that high BPA concentrations $[>10 \mu \mathrm{M}]$ exceed clinically-relevant exposure concentrations; however, reporting the observed effects may hint to BPA's underlying mechanisms and also allows for direct comparison between toxicological studies.

B. In vivo exposure studies-A few studies have examined the cardiac effects of BPA using an in vivo mammalian model ${ }^{125,127}$. Lifelong BPA exposure [0.5 - $\left.5 \mathrm{mg} / \mathrm{kg} / \mathrm{day}\right]$ was shown to modify cardiac structure and function in mice ${ }^{127}$. Similar to previous reports, Patel et al. identified sex-specific differences following BPA exposure, including concentric 
remodeling (male), increased systolic and diastolic blood pressure (female) and modified calcium handling protein expression (male \& female). Interestingly, the authors reported a reduced ability to remove and store calcium in female rats - a result that contradicts data from previously published in vitro studies ${ }^{119,120}$. These conflicting results may be due to a compensatory effect resulting from long-term BPA exposure, and highlight the importance of assessing toxicity using multiple models and time points. In vivo toxicity studies have also reported respiratory arrest, bradycardia and hypotension following intravenous injection with a lethal dose of BPA $[40 \mathrm{mg} / \mathrm{kg}]^{125}$.

C. Potential mechanisms-BPA has been shown to act as an estrogen agonist via ER $\beta$, whereas it has dual actions as an agonist and antagonist via ERa depending on cell type ${ }^{128}$. BPA's effect on estrogen receptors has been shown to increase contractility and spontaneous after contractions in female ventricular cells, and increase arrhythmia duration in female excised hearts via ER $\beta$ signaling ${ }^{121,129-131}$. These effects are likely mediated via protein kinase $\mathrm{A}$ and $\mathrm{Ca} 2+/ \mathrm{CaM}$-dependent protein kinase II signaling pathways, which modify the phosphorylation state of phospholamban and ryanodine receptors resulting in increased SR calcium leak and load ${ }^{131}$. The authors note that BPA's cardiac effects are gender specific, as similar effects were not observed in male ventricular myocytes. These cardiac effects were abolished in ER $\beta$ knockouts, overiectomized females, and by pretreatment with ER blockers, but not by pretreatment with L-NAME a nitric oxide (NO) synthase inhibitor. Conversely, Pant et al. observed a decrease in atrial rate and contractility following BPA exposure [1 $100 \mu \mathrm{M}]$; these effects were blocked by pretreatment with methylene blue or L-NAME ${ }^{126}$. Importantly, alterations in NO/cGMP signaling are biphasic and concentration dependent, which may explain experimental differences with L-NAME pretreatment ${ }^{132}$.

BPA has also been shown to interact directly with multiple ion channels. Using HEK293 cells, O'Reilly et al. showed that BPA binds directly to and blocks the human Nav1.5 sodium channel ${ }^{133}$, which is responsible for phase 0 depolarization in ventricular myocytes. Inhibition of the fast sodium current by BPA could explain the reduction in epicardial conduction velocity we observed in our ex vivo heart studies. BPA has also been shown to block multiple voltage-activated calcium channels, including L-type calcium channels which are responsible for the plateau phase of ventricular action potentials and phase 0 depolarization in sinoatrial cells ${ }^{134}$. This effect may explain the decreased heart rate observed following BPA exposure. Finally, BPA was recently shown to activate Maxi-K channels in coronary smooth muscle cells ${ }^{135}$. Although these channels are found in the mitochondria of cardiomyocytes, a similar interaction with sarcolemma potassium channels could hyperpolarize and decrease cardiac excitability.

D. Epidemiological studies-Higher BPA urine concentrations have been associated with an increased risk of coronary artery disease ${ }^{14,15,136}$, hypertension ${ }^{16}$, carotid atherosclerosis ${ }^{17}$, angina and myocardial infarction ${ }^{14,18}$, and decreased heart rate variability ${ }^{19}$. Higher BPA urinary levels have also been associated with LDL and HDL cholesterol levels ${ }^{83}$, and the echogenicity of vascular plaques ${ }^{17}$. Notably, these positive associations were observed at urinary concentrations that fall below the exposure levels observed in industrial workers and NICU patients ${ }^{12,99}$. To the best of our knowledge, 
epidemiological studies examining a link between BPA exposure and cardiac toxicity has not been investigated in these highly susceptible populations. It is important to note that the associations between BPA urinary levels and cardiovascular disease were not reproducible in an alternative study, which analyzed the National Health and Nutrition Examination Survey (NHANES) data using alternative inclusion parameters ${ }^{22}$. This highlights the importance of conducting toxicological experimental studies to fully understand the impact of endocrine disrupting chemicals on cardiovascular disease.

\section{Questions remaining}

\section{How does the presence of blood alter EDC adverse effects?}

Drug efficiency is influenced by plasma protein binding, which diminishes drug uptake to target organs and interaction with target receptors. The bound or inactive form of BPA represents $90-95 \%$ of total BPA in the blood ${ }^{137-139}$, whereas $80 \%$ of total DEHP is bound to lipoproteins and albumin ${ }^{140-142}$. Since many in vitro and ex vivo studies are conducted in serum-free or low albumin-containing solutions, additional studies are warranted to determine whether protein binding diminishes the bioavailability of these chemicals to such an extent that cardiotoxicity is irrelevant. Indeed, this question of bioavailability has been argued by researchers in the field $111,138,143$.

\section{Does chronic EDC exposure result in adverse cardiac effects in vivo?}

Some argue that EDC exposure is not a significant risk to humans because DEHP and BPA are rapidly metabolized ${ }^{143,144}$. However, it is actively debated whether these EDCs are immediately cleared from the body ${ }^{145-147}$ and pharmacokinetic studies are frequently based on acute exposure ${ }^{138,148-150}$, which differs from typical everyday human EDC exposure (the latter is likely to be a continuous, low dose exposure via ingestion). Many of these studies also fail to take into account differences in age-dependent differences in metabolic capacity ${ }^{151}$. Published pharmacokinetic studies estimate DEHP and BPA half-lives of 1-7 hours, and total elimination time to be $1-6$ days ${ }^{148-150,152,153}$. Importantly, changes in cardiac function have been observed following acute EDC exposure, within a time frame that is less than the above reported half-lives, by both our lab and others (Table $2 \& 5$ ). Moreover, chronic EDC exposure may result in tissue accumulation or longer elimination times ${ }^{154,155}$ due to accumulation in lipid-rich tissues ${ }^{156-158}$. Indeed, at least one study detected postexchange serum DEHP that were higher than the corresponding concentration in blood units, which indicates accumulation in newborn patients ${ }^{48}$. To fully address the risk of EDCs to the cardiovascular system and the impact of metabolic system, additional in vivo experiments are needed that more closely mimic chronic human exposure.

\section{Are high-risk subjects more susceptible to adverse EDC cardiac effects?}

Experimental studies have revealed electrical abnormalities in excised hearts, ventricular and atrial cells exposed to DEHP or BPA. Even if exposure to these EDCs does not elicit detrimental phenotypes in healthy individuals, it is plausible that chronic EDC exposure may exacerbate conduction and contractile abnormalities in high risk subjects, such as neonates, the elderly, or those with pre-existing heart conditions. Indeed, conduction and contractility disturbances are a common complication of myocardial infarction and heart failure ${ }^{159-167}$. 
Alternatively, elderly patients are prone to cardiac fibrosis, which increases ventricular stiffness and impairs diastolic function, ultimately diminishing the heart's ability to meet increased demand ${ }^{168}$. Moreover, cardiac fibrosis can affect the conduction system resulting in slowed conduction velocity, reentrant currents and arrhythmias ${ }^{169,170}$. Such pathological phenotypes can be exacerbated by the adverse cardiac effects of EDCs. Furthermore, EDC exposure during fetal and infant development can produce a range of adverse effects resulting from altered endocrine function ${ }^{63,116}$. As previously mentioned, these patients are vulnerable to high levels of exposure in the medical setting ${ }^{12,24}$, and questions regarding EDC metabolism and accumulation remain.

\section{Do EDCs affect human cardiomyocyte function?}

With the exception of two reports, which showed that MEHP exposure had a negative inotropic effect on human trabeculae fibers and elicited arrhythmic patterns ${ }^{42,74}$, DEHP and BPA exposure studies have been limited to chick and rodent models (Tables $2 \& 5$ ). Species differences in cardiac physiology are well documented ${ }^{171,172}$, and highlight the importance of not automatically assuming human cardiac toxicity based solely on alternative species models. To further understand the clinical impact of EDCs on cardiac physiology, more systematic studies should be conducted that examine the electrical and mechanical effects of EDCs using either human cardiac tissue samples or human stem cell-derived cardiomyocytes (hESC-CM). hESC-CM are a viable option since these cells have been fully characterized in terms of electrophysiology, calcium handling, and receptor response ${ }^{173}$, and have also been used as models to assess contractile impairment, arrhythmias, drug discovery, and as a toxicological screening tool ${ }^{174-178}$. Indeed, our recent studies suggest that human cardiomyocytes may be more sensitive to the effects of EDCs compared with rodent cells ${ }^{179}$.

\section{What about DEHP and BPA alternatives?}

There is an increasing availability of alternatives to DEHP and BPA, due largely in part to consumer wariness of the potential health effects raised by scientific and advocacy groups. Specifically, 1,2-Cyclohexane dicarboxylic acid diisononyl ester $\left(\right.$ Hexmoll $\left.\mathrm{DINCH}^{\mathrm{TM}}\right)$, Tris(2-ethylhexyl) trimelliate (TOTM), Di(2-ethylhexyl) adipate (DEHA) and two citrates, Butyryl trihexyl citrate (BTHC) and Acetyl tributyl citrate (ATBC) are the main DEHP alternatives currently used in PVC-containing medical products. BPA polycarbonate plastic alternatives include Bisphenol S (BPS) and Tritan Copolyester ${ }^{\mathrm{TM}}$, and alternative liners, such as EcoCare ${ }^{\mathrm{TM}}$ and oleoresin. The appeal to these alternatives is two-fold; first and foremost, most of these chemicals appear to be less toxic compared with DEHP or BPA, and second, these alternatives can be marketed as "phthalate-free" which appeals to consumers. Unsurprisingly, all of these plastic additives have their own individual drawbacks ${ }^{180-186}$, including: higher price, less efficiency, significant leaching, insufficient purity, and adverse health effects. The major drawback to these alternative products is that they are relatively untested and the toxicological data on these substitutes is extremely limited. To the best of our knowledge, there are no existing scientific studies that have examined these any of these alternatives with regard to cardiotoxicity. 


\section{Conclusion}

Our current understanding of DEHP and BPA toxicity is primarily a result of human epidemiological observations and high dose effects observed in the laboratory. Epidemiological or cross-sectional studies are useful in identifying associations between EDC exposure and adverse health conditions, but they can only identify correlations and not causal links between exposure and disease. Whereas, research studies that employ high exposure levels hamper direct extrapolation to humans. Ideally, experimental studies should be designed to examine clinically-relevant concentrations in both an in vitro model, which allows one to elucidate the direct effects of EDC exposure, and in vivo model, since exposure can affect organ systems differently and because a fully functioning metabolic system is present. In addition, large scale epidemiological studies that are designed to comprehensively examine multiple cardiovascular parameters, including: blood pressure, incidence of plaques, echocardiography and electrocardiography, would greatly improve our understanding of toxicity to the general population.

Additional studies are necessary to clarify gaps in our current understanding of DEHP and BPA cardiac toxicity and determine the applicability of our findings to humans. These include, 1) determining the direct effect of EDCs on cardiac physiology at clinically-relevant concentrations and clarifying to what extent the presence of plasma-binding proteins negate these effects, 2) identifying whether long-term EDC exposure negatively impacts cardiovascular function in vivo, and 3) ascertaining patient populations that are most susceptible to EDC cardiac toxicity. These studies are particularly important, as sustained exposure to EDCs may cause and/or exacerbate conduction abnormalities in individuals with preexisting heart conditions (e.g., AV conduction dysfunction, bradycardia, atherosclerosis, myocardial infarction), or other high-risk populations (e.g., industrial workers, prenatal and neonatal patients with reduced metabolic capacity, elderly patients with substantial fibrosis), 4) determining the applicability of these previous findings with human cells and/or tissue. Thorough examination of DEHP and BPA cardiac toxicity using these experimental models should resolve the controversy as to whether EDC exposure negatively impacts the cardiovascular system, and provide the foundation for objective decision making by the public, scientific, medical and regulatory communities.

\section{Acknowledgments}

The author thanks Dr. Narine Sarvazyan and Dr. Matthew Kay for helpful discussions.

Funding: This work was supported by the National Institutes of Health [F32ES019057] and [K99ES023477]

\section{Abbreviations}

$\begin{array}{ll}\text { BPA } & \text { Bisphenol A } \\ \text { DEHP } & \text { Di(2-ethylhexyl) phthalate } \\ \text { EDCs } & \text { Endocrine disrupting chemicals } \\ \text { MEHP } & \text { Mono(2-ethylhexyl) phthalate }\end{array}$




\section{References}

1. Halden RU. Plastics and health risks. Annu Rev Public Health. 2010; 31:179-194. [PubMed: 20070188]

2. Casals-Casas C, Desvergne B. Endocrine disruptors: from endocrine to metabolic disruption. Annu Rev Physiol. 2011; 73:135-162. [PubMed: 21054169]

3. Diamanti-Kandarakis E, et al. Endocrine-disrupting chemicals: an Endocrine Society scientific statement. Endocr Rev. 2009; 30:293-342. [PubMed: 19502515]

4. Vandenberg LN, Hauser R, Marcus M, Olea N, Welshons WV. Human exposure to bisphenol A (BPA). Reprod Toxicol. 2007; 24:139-177. [PubMed: 17825522]

5. Wittassek M, Koch HM, Angerer J, Brüning T. Assessing exposure to phthalates - the human biomonitoring approach. Mol Nutr Food Res. 2011; 55:7-31. [PubMed: 20564479]

6. Rubin BS. Bisphenol A: an endocrine disruptor with widespread exposure and multiple effects. J Steroid Biochem Mol Biol. 2011; 127:27-34. [PubMed: 21605673]

7. Schettler T. Human exposure to phthalates via consumer products. Int J Androl. 2006; 29:134-9. discussion 181-5. [PubMed: 16466533]

8. Calafat AM, Needham LL, Silva MJ, Lambert G. Exposure to di-(2-ethylhexyl) phthalate among premature neonates in a neonatal intensive care unit. Pediatrics. 2004; 113:e429-34. [PubMed: 15121985]

9. Silva MJ, et al. Urinary levels of seven phthalate metabolites in the U.S. population from the National Health and Nutrition Examination Survey (NHANES) 1999-2000. Environ Health Perspect. 2004; 112:331-338. [PubMed: 14998749]

10. Wittassek M, et al. Internal phthalate exposure over the last two decades--a retrospective human biomonitoring study. Int J Hyg Environ Health. 2007; 210:319-333. [PubMed: 17400024]

11. Calafat AM, Ye X, Wong LY, Reidy JA, Needham LL. Exposure of the U.S. population to bisphenol A and 4-tertiary-octylphenol: 2003-2004. Environ Health Perspect. 2008; 116:39-44. [PubMed: 18197297]

12. Calafat AM, et al. Exposure to bisphenol A and other phenols in neonatal intensive care unit premature infants. Environ Health Perspect. 2009; 117:639-644. [PubMed: 19440505]

13. Green R, et al. Use of di(2-ethylhexyl) phthalate-containing medical products and urinary levels of mono(2-ethylhexyl) phthalate in neonatal intensive care unit infants. Environ Health Perspect. 2005; 113:1222-1225. [PubMed: 16140631]

14. Melzer D, Rice NE, Lewis C, Henley WE, Galloway TS. Association of urinary bisphenol a concentration with heart disease: evidence from NHANES 2003/06. PLoS One. 2010; 5:e8673. [PubMed: 20084273]

15. Melzer D, et al. Urinary bisphenol A concentration and risk of future coronary artery disease in apparently healthy men and women. Circulation. 2012; 125:1482-1490. [PubMed: 22354940]

16. Shankar A, Teppala S, Sabanayagam C. Bisphenol A and Peripheral Arterial Disease: Results from the NHANES. Environ Health Perspect. 201210.1289/ehp.1104114

17. Lind PM, Lind L. Circulating levels of bisphenol A and phthalates are related to carotid atherosclerosis in the elderly. Atherosclerosis. 2011; 218:207-213. [PubMed: 21621210]

18. Lang IA, et al. Association of urinary bisphenol A concentration with medical disorders and laboratory abnormalities in adults. JAMA. 2008; 300:1303-1310. [PubMed: 18799442]

19. Bae S, Kim JH, Lim YH, Park HY, Hong YC. Associations of bisphenol A exposure with heart rate variability and blood pressure. Hypertension. 2012; 60:786-93. [PubMed: 22851732]

20. Trasande L, et al. Urinary phthalates are associated with higher blood pressure in childhood. J Pediatr. 2013; 163:747-53.e1. [PubMed: 23706605]

21. Khalil N, et al. Bisphenol A and cardiometabolic risk factors in obese children. Sci Total Environ. 2013; 470-471C:726-732.

22. LaKind JS, Goodman M, Naiman DQ. Use of NHANES data to link chemical exposures to chronic diseases: a cautionary tale. PLoS One. 2012; 7:e51086. [PubMed: 23227235]

23. Jaeger RJ, Rubin RJ. Extraction, localization, and metabolism of di-2-ethylhexyl phthalate from PVC plastic medical devices. Environ Health Perspect. 1973; 3:95-102. [PubMed: 4735799] 
24. FDA. Safety Assessment of Di(2-ethylhexyl)phthalate (DEHP) Released from PVC Medical Devices. 2002. http://www

25. Marcel YL. Determination of di-2-ethylhexyl phthalate levels in human blood plasma and cryoprecipitates. Environ Health Perspect. 1973; 3:119-121. [PubMed: 4704559]

26. Loff $\mathrm{S}$, et al. Polyvinylchloride infusion lines expose infants to large amounts of toxic plasticizers. J Pediatr Surg. 2000; 35:1775-1781. [PubMed: 11101735]

27. Peck CC, Albro PW. Toxic potential of the plasticizer Di(2-ethylhexyl) phthalate in the context of its disposition and metabolism in primates and man. Environ Health Perspect. 1982; 45:11-17. [PubMed: 7140682]

28. Rubin RJ, Jaeger RJ. Some Pharmacologic and Toxicologic Effects of Di-2-Ethylhexyl Phthalate (DEHP) and Other Plasticizers. Environ Health Perspect. 1973; 3:53-59. [PubMed: 4704572]

29. Latini G, Avery GB. Materials degradation in endotracheal tubes: a potential contributor to bronchopulmonary dysplasia. Acta Paediatr. 1999; 88:1174-1175. [PubMed: 10565474]

30. Danschutter D, et al. Di-(2-ethylhexyl)phthalate and deep venous thrombosis in children: a clinical and experimental analysis. Pediatrics. 2007; 119:e742-53. [PubMed: 17325211]

31. Li LX, et al. Exposure levels of environmental endocrine disruptors in mother-newborn pairs in China and their placental transfer characteristics. PLoS One. 2013; 8:e62526. [PubMed: 23667484]

32. Latini G, et al. Exposure to Di(2-ethylhexyl)phthalate in humans during pregnancy. A preliminary report. Biol Neonate. 2003; 83:22-4. [PubMed: 12566679]

33. Zhang Y, et al. Phthalate levels and low birth weight: a nested case-control study of Chinese newborns. J Pediatr. 2009; 155:500-4. [PubMed: 19555962]

34. Latini G, et al. In utero exposure to di-(2-ethylhexyl)phthalate and duration of human pregnancy. Environ Health Perspect. 2003; 111:1783-5. [PubMed: 14594632]

35. Huang Y, et al. Phthalate levels in cord blood are associated with preterm delivery and fetal growth parameters in chinese women. PLoS One. 2014; 9:e87430. [PubMed: 24503621]

36. Hoppin JA, Brock JW, Davis BJ, Baird DD. Reproducibility of urinary phthalate metabolites in first morning urine samples. Environ Health Perspect. 2002; 110:515-8. [PubMed: 12003755]

37. Yolton K, et al. Prenatal exposure to bisphenol A and phthalates and infant neurobehavior. Neurotoxicol Teratol. 33:558-66. [PubMed: 21854843]

38. Whyatt RM, et al. Prenatal di(2-ethylhexyl)phthalate exposure and length of gestation among an inner-city cohort. Pediatrics. 2009; 124:e1213-20. [PubMed: 19948620]

39. Swan SH, et al. Prenatal phthalate exposure and reduced masculine play in boys. Int J Androl. 2010; 33:259-69. [PubMed: 19919614]

40. Brock JW, Caudill SP, Silva MJ, Needham LL, Hilborn ED. Phthalate monoesters levels in the urine of young children. Bull Environ Contam Toxicol. 2002; 68:309-14. [PubMed: 11993803]

41. Teitelbaum SL, et al. Temporal variability in urinary concentrations of phthalate metabolites, phytoestrogens and phenols among minority children in the United States. Environ Res. 2008; 106:257-69. [PubMed: 17976571]

42. Barry YA, Labow RS, Keon WJ, Tocchi M, Rock G. Perioperative exposure to plasticizers in patients undergoing cardiopulmonary bypass. J Thorac Cardiovasc Surg. 1989; 97:900-905. [PubMed: 2657224]

43. Pollack GM, Buchanan JF, Slaughter RL, Kohli RK, Shen DD. Circulating concentrations of di(2ethylhexyl) phthalate and its de-esterified phthalic acid products following plasticizer exposure in patients receiving hemodialysis. Toxicol Appl Pharmacol. 1985; 79:257-67. [PubMed: 4002227]

44. Faouzi MA, et al. Exposure of hemodialysis patients to di-2-ethylhexyl phthalate. Int J Pharm. 1999; 180:113-21. [PubMed: 10089298]

45. Buchta C, et al. Transfusion-related exposure to the plasticizer di(2-ethylhexyl)phthalate in patients receiving plateletpheresis concentrates. Transfusion. 2005; 45:798-802. [PubMed: 15847671]

46. Weuve J, et al. Exposure to phthalates in neonatal intensive care unit infants: urinary concentrations of monoesters and oxidative metabolites. Environ Health Perspect. 2006; 114:1424-31. [PubMed: 16966100] 
47. Sjoberg PO, Bondesson UG, Sedin EG, Gustafsson JP. Exposure of newborn infants to plasticizers. Plasma levels of di-(2-ethylhexyl) phthalate and mono-(2-ethylhexyl) phthalate during exchange transfusion. Transfusion. 1985; 25:424-428. [PubMed: 4049487]

48. Plonait SL, Nau H, Maier RF, Wittfoht W, Obladen M. Exposure of newborn infants to di-(2ethylhexyl)-phthalate and 2-ethylhexanoic acid following exchange transfusion with polyvinylchloride catheters. Transfusion. 1993; 33:598-605. [PubMed: 8333024]

49. Shneider B, Schena J, Truog R, Jacobson M, Kevy S. Exposure to di(2-ethylhexyl)phthalate in infants receiving extracorporeal membrane oxygenation. N Engl J Med. 1989; 320:1563. [PubMed: 2725593]

50. Karle VA, et al. Extracorporeal membrane oxygenation exposes infants to the plasticizer, di(2ethylhexyl)phthalate. Crit Care Med. 1997; 25:696-703. [PubMed: 9142038]

51. Sjoberg P, Bondesson U, Sedin G, Gustafsson J. Dispositions of di- and mono-(2-ethylhexyl) phthalate in newborn infants subjected to exchange transfusions. Eur J Clin Invest. 1985; 15:430436. [PubMed: 3938415]

52. Peck CC, et al. Di-2-ethylhexyl phthalate (DEHP) and mono-2-ethylexyl phthalate (MEHP) accumulation in whole blood and red cell concentrates. Transfusion. 1979; 19:137-146. [PubMed: 432924]

53. Carlson K. Toxicity Review of Di (2-ethylhexyl) Phthalate (DEHP). 2010

54. Swan SH, et al. Decrease in anogenital distance among male infants with prenatal phthalate exposure. Environ Health Perspect. 2005; 113:1056-1061. [PubMed: 16079079]

55. Hauser R, Meeker JD, Duty S, Silva MJ, Calafat AM. Altered semen quality in relation to urinary concentrations of phthalate monoester and oxidative metabolites. Epidemiology. 2006; 17:682691. [PubMed: 17003688]

56. Duty SM, et al. The relationship between environmental exposures to phthalates and DNA damage in human sperm using the neutral comet assay. Environ Health Perspect. 2003; 111:1164-1169. [PubMed: 12842768]

57. Joensen UN, et al. Phthalate excretion pattern and testicular function: a study of 881 healthy Danish men. Environ Health Perspect. 2012; 120:1397-1403. [PubMed: 22832070]

58. Colon I, Caro D, Bourdony CJ, Rosario O. Identification of phthalate esters in the serum of young Puerto Rican girls with premature breast development. Environ Health Perspect. 2000; 108:895900. [PubMed: 11017896]

59. Stahlhut RW, van Wijngaarden E, Dye TD, Cook S, Swan SH. Concentrations of urinary phthalate metabolites are associated with increased waist circumference and insulin resistance in adult U.S. males. Environ Health Perspect. 2007; 115:876-882. [PubMed: 17589594]

60. Meeker JD, et al. Urinary phthalate metabolites in relation to preterm birth in Mexico city. Environ Health Perspect. 2009; 117:1587-92. [PubMed: 20019910]

61. Parks LG, et al. The plasticizer diethylhexyl phthalate induces malformations by decreasing fetal testosterone synthesis during sexual differentiation in the male rat. Toxicol Sci. 2000; 58:339-349. [PubMed: 11099646]

62. Sharpe RM. Hormones and testis development and the possible adverse effects of environmental chemicals. Toxicol Lett. 2001; 120:221-232. [PubMed: 11323180]

63. Braun JM, Sathyanarayana S, Hauser R. Phthalate exposure and children's health. Curr Opin Pediatr. 2013; 25:247-254. [PubMed: 23429708]

64. Prevention C for D. C. Third National Report on Human Exposure to Environmental Chemicals. 2005

65. Leeder JS, Kearns GL. Pharmacogenetics in pediatrics. Implications for practice. Pediatr Clin North Am. 1997; 44:55-77. [PubMed: 9057784]

66. Jahnke GD, Iannucci AR, Scialli AR, Shelby MD. Center for the evaluation of risks to human reproduction--the first five years. Birth defects Res B, Dev Reprod Toxicol. 2005; 74:1-8. [PubMed: 15729732]

67. Kavlock R, et al. NTP Center for the Evaluation of Risks to Human Reproduction: phthalates expert panel report on the reproductive and developmental toxicity of di(2-ethylhexyl) phthalate. Reprod Toxicol. 2002; 16:529-653. [PubMed: 12406494] 
68. Shea KM. Pediatric Exposure and Potential Toxicity of Phthalate Plasticizers. Pediatrics. 2003; 111:1467-1474. [PubMed: 12777573]

69. Von Rettberg H, et al. Use of di(2-ethylhexyl)phthalate-containing infusion systems increases the risk for cholestasis. Pediatrics. 2009; 124:710-6. [PubMed: 19651587]

70. Gillum N, et al. Clinically relevant concentrations of di (2-ethylhexyl) phthalate (DEHP) uncouple cardiac syncytium. Toxicol Appl Pharmacol. 2009; 236:25-38. [PubMed: 19344669]

71. Aronson CE, Serlick ER, Preti G. Effects of di-2-ethylhexyl phthalate on the isolated perfused rat heart. Toxicol Appl Pharmacol. 1978; 44:155-169. [PubMed: 675687]

72. Schulpen SHW, Robinson JF, Pennings JLA, van Dartel DAM, Piersma AH. Dose response analysis of monophthalates in the murine embryonic stem cell test assessed by cardiomyocyte differentiation and gene expression. Reprod Toxicol. 2013; 35:81-8. [PubMed: 22813628]

73. Rock G, Labow RS, Franklin C, Burnett R, Tocchi M. Hypotension and cardiac arrest in rats after infusion of mono(2-ethylhexyl) phthalate (MEHP), a contaminant of stored blood. N Engl J Med. 1987; 316:1218-1219. [PubMed: 3574376]

74. Barry YA, Labow RS, Keon WJ, Tocchi M. Atropine inhibition of the cardiodepressive effect of mono(2-ethylhexyl)phthalate on human myocardium. Toxicol Appl Pharmacol. 1990; 106:48-52. [PubMed: 2251683]

75. Hillman LS, Goodwin SL, Sherman WR. Identification and measurement of plasticizer in neonatal tissues after umbilical catheters and blood products. N Engl J Med. 1975; 292:381-386. [PubMed: 1110722]

76. Martinez-Arguelles DB, et al. Maternal in utero exposure to the endocrine disruptor di-(2ethylhexyl) phthalate affects the blood pressure of adult male offspring. Toxicol Appl Pharmacol. 2013; 266:95-100. [PubMed: 23142467]

77. Wei Z, et al. Maternal exposure to di-(2-ethylhexyl)phthalate alters kidney development through the renin-angiotensin system in offspring. Toxicol Lett. 2012; 212:212-21. [PubMed: 22677342]

78. Calley D, Autian J, Guess WL. Toxicology of a series of phthalate esters. J Pharm Sci. 1966; 55:158-62. [PubMed: 5923262]

79. Posnack NG, Lee NH, Brown R, Sarvazyan N. Gene expression profiling of DEHP-treated cardiomyocytes reveals potential causes of phthalate arrhythmogenicity. Toxicology. 2011; 279:54-64. [PubMed: 20920545]

80. Posnack NG, Swift LM, Kay MW, Lee NH, Sarvazyan N. Phthalate Exposure Changes the Metabolic Profile of Cardiac Muscle Cells. Environ Health Perspect. 2012; 120:1243-1251. [PubMed: 22672789]

81. Mangala Priya V, Mayilvanan C, Akilavalli N, Rajesh P, Balasubramanian K. Lactational exposure of phthalate impairs insulin signaling in the cardiac muscle of $\mathrm{f} 1 \mathrm{female}$ albino rats. Cardiovasc Toxicol. 2014; 14:10-20. [PubMed: 24297258]

82. Feige JN, et al. The pollutant diethylhexyl phthalate regulates hepatic energy metabolism via species-specific PPARalpha-dependent mechanisms. Environ Health Perspect. 2010; 118:234 241. [PubMed: 20123618]

83. Olsén L, Lind L, Lind PM. Associations between circulating levels of bisphenol A and phthalate metabolites and coronary risk in the elderly. Ecotoxicol Environ Saf. 2012; 80:179-83. [PubMed: 22421452]

84. Brotons JA, Olea-Serrano MF, Villalobos M, Pedraza V, Olea N. Xenoestrogens released from lacquer coatings in food cans. Environ Health Perspect. 1995; 103:608-12. [PubMed: 7556016]

85. Kang JH, Kito K, Kondo F. Factors influencing the migration of bisphenol A from cans. J Food Prot. 2003; 66:1444-7. [PubMed: 12929833]

86. Calafat AM, et al. Urinary concentrations of bisphenol A and 4-nonylphenol in a human reference population. Environ Health Perspect. 2005; 113:391-395. [PubMed: 15811827]

87. Bushnik T, et al. Lead and bisphenol A concentrations in the Canadian population. Heal reports. 2010; 21:7-18.

88. Mendiola J, et al. Are environmental levels of bisphenol a associated with reproductive function in fertile men? Environ Health Perspect. 2010; 118:1286-91. [PubMed: 20494855]

89. Genuis SJ, Beesoon S, Birkholz D, Lobo RA. Human excretion of bisphenol A: blood, urine, and sweat (BUS) study. J Environ Public Health. 2012; 2012:185731. [PubMed: 22253637] 
90. Heffernan AL, et al. Age-related trends in urinary excretion of bisphenol A in Australian children and adults: evidence from a pooled sample study using samples of convenience. J Toxicol Environ Health A. 2013; 76:1039-55. [PubMed: 24188190]

91. Zhang T, Sun H, Kannan K. Blood and urinary bisphenol A concentrations in children, adults, and pregnant women from china: partitioning between blood and urine and maternal and fetal cord blood. Environ Sci Technol. 2013; 47:4686-94. [PubMed: 23506159]

92. Braun JM, et al. Variability and predictors of urinary bisphenol A concentrations during pregnancy. Environ Health Perspect. 2011; 119:131-7. [PubMed: 21205581]

93. Morgan MK, et al. Assessing the quantitative relationships between preschool children's exposures to bisphenol A by route and urinary biomonitoring. Environ Sci Technol. 2011; 45:5309-16. [PubMed: 21612268]

94. Becker K, et al. GerES IV: phthalate metabolites and bisphenol A in urine of German children. Int J Hyg Environ Health. 2009; 212:685-92. [PubMed: 19729343]

95. Völkel W, Kiranoglu M, Fromme H. Determination of free and total bisphenol A in urine of infants. Environ Res. 2011; 111:143-8. [PubMed: 20970783]

96. Sathyanarayana S, Braun JM, Yolton K, Liddy S, Lanphear BP. Case report: high prenatal bisphenol a exposure and infant neonatal neurobehavior. Environ Health Perspect. 2011; 119:1170-5. [PubMed: 21524981]

97. Patel CJ, et al. Investigation of maternal environmental exposures in association with self-reported preterm birth. Reprod Toxicol. 2013; 45C:1-7. [PubMed: 24373932]

98. Braun JM, et al. Impact of early-life bisphenol A exposure on behavior and executive function in children. Pediatrics. 2011; 128:873-82. [PubMed: 22025598]

99. Wang F, et al. High urinary bisphenol A concentrations in workers and possible laboratory abnormalities. Occup Environ Med. 201210.1136/oemed-2011-100529

100. Duty SM, et al. Potential sources of bisphenol A in the neonatal intensive care unit. Pediatrics. 2013; 131:483-9. [PubMed: 23420909]

101. Aris A. Estimation of bisphenol A (BPA) concentrations in pregnant women, fetuses and nonpregnant women in Eastern Townships of Canada. Reprod Toxicol. 2013; 45C:8-13. [PubMed: 24378374]

102. Lee YJ, et al. Maternal and fetal exposure to bisphenol A in Korea. Reprod Toxicol. 2008; 25:413-419. [PubMed: 18577445]

103. Padmanabhan V, et al. Maternal bisphenol-A levels at delivery: a looming problem? J Perinatol. 2008; 28:258-263. [PubMed: 18273031]

104. Schonfelder G, et al. Parent bisphenol A accumulation in the human maternal-fetal-placental unit. Environ Health Perspect. 2002; 110:A703-7. [PubMed: 12417499]

105. Vandenberg LN, et al. Urinary, circulating, and tissue biomonitoring studies indicate widespread exposure to bisphenol A. Environ Health Perspect. 2010; 118:1055-1070. [PubMed: 20338858]

106. Krieter DH, et al. Bisphenol A in chronic kidney disease. Artif Organs. 2013; 37:283-90. [PubMed: 23145999]

107. Sajiki J, et al. Determination of Bisphenol A (BPA) in Plasma of Hemodialysis Patients Using Three Methods: LC/ECD, LC/MS, and ELISA. Toxicol Mech Methods. 2008; 18:733-8. [PubMed: 20020932]

108. Kanno Y, Okada H, Kobayashi T, Takenaka T, Suzuki H. Effects of endocrine disrupting substance on estrogen receptor gene transcription in dialysis patients. Ther Apher Dial. 2007; 11:262-5. [PubMed: 17661831]

109. Cobellis L, Colacurci N, Trabucco E, Carpentiero C, Grumetto L. Measurement of bisphenol A and bisphenol B levels in human blood sera from healthy and endometriotic women. Biomed Chromatogr. 2009; 23:1186-90. [PubMed: 19444800]

110. Teeguarden JG, Hanson-Drury S. A systematic review of Bisphenol A "low dose" studies in the context of human exposure: a case for establishing standards for reporting "low-dose" effects of chemicals. Food Chem Toxicol. 2013; 62:935-48. [PubMed: 23867546]

111. Vandenberg LN, Hunt PA, Myers JP, Vom Saal FS. Human exposures to bisphenol A: mismatches between data and assumptions. Rev Environ Health. 2013; 28:37-58. [PubMed: 23612528] 
112. Meeker JD, et al. Semen quality and sperm DNA damage in relation to urinary bisphenol A among men from an infertility clinic. Reprod Toxicol. 2010; 30:532-539. [PubMed: 20656017]

113. Yang M, Ryu JH, Jeon R, Kang D, Yoo KY. Effects of bisphenol A on breast cancer and its risk factors. Arch Toxicol. 2009; 83:281-285. [PubMed: 18843480]

114. Ehrlich S, et al. Urinary bisphenol A concentrations and early reproductive health outcomes among women undergoing IVF. Hum Reprod. 2012; 27:3583-3592. [PubMed: 23014629]

115. Hiroi $\mathrm{H}$, et al. Differences in serum bisphenol a concentrations in premenopausal normal women and women with endometrial hyperplasia. Endocr J. 2004; 51:595-600. [PubMed: 15644579]

116. Braun JM, Hauser R. Bisphenol A and children's health. Curr Opin Pediatr. 2011; 23:233-239. [PubMed: 21293273]

117. Markey CM, Michaelson CL, Veson EC, Sonnenschein C, Soto AM. The mouse uterotrophic assay: a reevaluation of its validity in assessing the estrogenicity of bisphenol A. Environ Health Perspect. 2001; 109:55-60. [PubMed: 11171525]

118. Markey CM, Wadia PR, Rubin BS, Sonnenschein C, Soto AM. Long-term effects of fetal exposure to low doses of the xenoestrogen bisphenol-A in the female mouse genital tract. Biol Reprod. 2005; 72:1344-1351. [PubMed: 15689538]

119. Yan S, et al. Bisphenol A and 17beta-estradiol promote arrhythmia in the female heart via alteration of calcium handling. PLoS One. 2011; 6:e25455. [PubMed: 21980463]

120. Belcher SM, Chen Y, Yan S, Wang HS. Rapid Estrogen Receptor-Mediated Mechanisms Determine the Sexually Dimorphic Sensitivity of Ventricular Myocytes to 17beta-Estradiol and the Environmental Endocrine Disruptor Bisphenol A. Endocrinology. 201110.1210/en. 2011-1772

121. Yan S, et al. Low-dose bisphenol A and estrogen increase ventricular arrhythmias following ischemia-reperfusion in female rat hearts. Food Chem Toxicol. 2013; 56:75-80. [PubMed: 23429042]

122. Posnack NG, et al. Bisphenol A Exposure and Cardiac Electrical Conduction in Excised Rat Hearts. Environ Health Perspect. 201410.1289/ehp.1206157

123. Schirling M, Bohlen A, Triebskorn R, Kohler HR. An invertebrate embryo test with the apple snail Marisa cornuarietis to assess effects of potential developmental and endocrine disruptors. Chemosphere. 2006; 64:1730-1738. [PubMed: 16481024]

124. Lee W, Kang CW, Su CK, Okubo K, Nagahama Y. Screening estrogenic activity of environmental contaminants and water samples using a transgenic medaka embryo bioassay. Chemosphere. 2012; 88:945-952. [PubMed: 22497783]

125. Pant J, Deshpande SB. Acute toxicity of bisphenol A in rats. Indian J Exp Biol. 2012; 50:425-9. [PubMed: 22734254]

126. Pant J, Ranjan P, Deshpande SB. Bisphenol A decreases atrial contractility involving NOdependent G-cyclase signaling pathway. J Appl Toxicol. 2011; 31:698-702. [PubMed: 21351110]

127. Patel BB, Raad M, Sebag IA, Chalifour LE. Lifelong exposure to bisphenol a alters cardiac structure/function, protein expression, and DNA methylation in adult mice. Toxicol Sci. 2013; 133:174-85. [PubMed: 23418087]

128. Kurosawa T, et al. The activity of bisphenol A depends on both the estrogen receptor subtype and the cell type. Endocr J. 2002; 49:465-71. [PubMed: 12402979]

129. Yan S, et al. Bisphenol A and $17 \beta$-estradiol promote arrhythmia in the female heart via alteration of calcium handling. PLoS One. 2011; 6:e25455. [PubMed: 21980463]

130. Belcher SM, Chen Y, Yan S, Wang HS. Rapid estrogen receptor-mediated mechanisms determine the sexually dimorphic sensitivity of ventricular myocytes to $17 \beta$-estradiol and the environmental endocrine disruptor bisphenol A. Endocrinology. 2012; 153:712-20. [PubMed: 22166976]

131. Gao X, Liang Q, Chen Y, Wang HS. Molecular mechanisms underlying the rapid arrhythmogenic action of bisphenol A in female rat hearts. Endocrinology. 2013; 154:4607-17. [PubMed: 24140712]

132. González DR, et al. Differential role of S-nitrosylation and the NO-cGMP-PKG pathway in cardiac contractility. Nitric Oxide. 2008; 18:157-67. [PubMed: 18023373] 
133. O'Reilly AO, et al. Bisphenol a binds to the local anesthetic receptor site to block the human cardiac sodium channel. PLoS One. 2012; 7:e41667. [PubMed: 22848561]

134. Willecke K, et al. Structural and functional diversity of connexin genes in the mouse and human genome. Biol Chem. 2002; 383:725-737. [PubMed: 12108537]

135. Asano S, Tune JD, Dick GM. Bisphenol A activates Maxi-K (K(Ca)1.1) channels in coronary smooth muscle. Br J Pharmacol. 2010; 160:160-170. [PubMed: 20331605]

136. Melzer D, et al. Urinary bisphenol a concentration and angiography-defined coronary artery stenosis. PLoS One. 2012; 7:e43378. [PubMed: 22916252]

137. Csanady GA, et al. Distribution and unspecific protein binding of the xenoestrogens bisphenol A and daidzein. Arch Toxicol. 2002; 76:299-305. [PubMed: 12107647]

138. Teeguarden JG, Waechter JM Jr, Clewell HJ 3rd, Covington TR, Barton HA. Evaluation of oral and intravenous route pharmacokinetics, plasma protein binding, and uterine tissue dose metrics of bisphenol A: a physiologically based pharmacokinetic approach. Toxicol Sci. 2005; 85:823838. [PubMed: 15746009]

139. Kurebayashi H, Harada R, Stewart RK, Numata H, Ohno Y. Disposition of a low dose of bisphenol a in male and female cynomolgus monkeys. Toxicol Sci. 2002; 68:32-42. [PubMed: 12075108]

140. Zhang H, Liu E. Binding behavior of DEHP to albumin: spectroscopic investigation. J Incl Phenom Macrocycl Chem. 2012; 74:231-238.

141. Sasakawa S, Mitomi Y. Di-2-ethylhexylphthalate (DEHP) content of blood or blood components stored in plastic bags. Vox Sang. 1978; 34:81-86. [PubMed: 622821]

142. Albro PW, Corbett JT. Distribution of di- and mono-(2-ethylhexyl) phthalate in human plasma. Transfusion. 1978; 18:750-755. [PubMed: 83042]

143. Teeguarden JG, et al. Twenty-four hour human urine and serum profiles of bisphenol a during high-dietary exposure. Toxicol Sci. 2011; 123:48-57. [PubMed: 21705716]

144. Hengstler JG, et al. Critical evaluation of key evidence on the human health hazards of exposure to bisphenol A. Crit Rev Toxicol. 2011; 41:263-291. [PubMed: 21438738]

145. Vom Saal FS, Prins GS, Welshons WV. Report of very low real-world exposure to bisphenol A is unwarranted based on a lack of data and flawed assumptions. Toxicol Sci. 2012; 125:315-318.

146. Teeguarden J, Calafat A, Doerge D. Adhering to Fundamental Principles of Biomonitoring, BPA Pharmacokinetics, and Mass Balance Is No "Flaw". Tox Sci. 2012; 125(1):321-325.

147. Kambia N, et al. Strong Variability of Di(2-ethylhexyl)phthalate (DEHP) Plasmatic Rate in Infants and Children Undergoing 12-Hour Cyclic Parenteral Nutrition. JPEN Journal Parenter Enter Nutr. 201210.1177/0148607112450914

148. Volkel W, Colnot T, Csanady GA, Filser JG, Dekant W. Metabolism and kinetics of bisphenol a in humans at low doses following oral administration. Chem Res Toxicol. 2002; 15:1281-1287. [PubMed: 12387626]

149. Koch HM, Angerer J, Drexler H, Eckstein R, Weisbach V. Di(2-ethylhexyl)phthalate (DEHP) exposure of voluntary plasma and platelet donors. Int J Hyg Environ Health. 2005; 208:489-498. [PubMed: 16325559]

150. Kessler W, et al. Kinetics of di(2-ethylhexyl) phthalate (DEHP) and mono(2-ethylhexyl) phthalate in blood and of DEHP metabolites in urine of male volunteers after single ingestion of ring-deuterated DEHP. Toxicol Appl Pharmacol. 2012; 264:284-291. [PubMed: 22963843]

151. Yang X, Doerge DR, Fisher JW. Prediction and evaluation of route dependent dosimetry of BPA in rats at different life stages using a physiologically based pharmacokinetic model. Toxicol Appl Pharmacol. 2013; 270:45-59. [PubMed: 23566954]

152. Shin BS, et al. Physiologically based pharmacokinetics of bisphenol A. J Toxicol Environ Heal A. 2004; 67:1971-1985.

153. Koch HM, Preuss R, Angerer J. Di(2-ethylhexyl)phthalate (DEHP): human metabolism and internal exposure-- an update and latest results. Int J Androl. 2006; 29:155. [PubMed: 16466535]

154. Sieli PT, et al. Comparison of serum bisphenol A concentrations in mice exposed to bisphenol A through the diet versus oral bolus exposure. Environ Health Perspect. 2011; 119:1260-1265. [PubMed: 21642047] 
155. Stahlhut RW, Welshons WV, Swan SH. Bisphenol A data in NHANES suggest longer than expected half-life, substantial nonfood exposure, or both. Environ Health Perspect. 2009; 117:784-789. [PubMed: 19479022]

156. Nunez AA, Kannan K, Giesy JP, Fang J, Clemens LG. Effects of bisphenol A on energy balance and accumulation in brown adipose tissue in rats. Chemosphere. 2001; 42:917-922. [PubMed: 11272914]

157. Fernandez MF, et al. Bisphenol-A and chlorinated derivatives in adipose tissue of women. Reprod Toxicol. 2007; 24:259-264. [PubMed: 17689919]

158. Herreros MA, et al. Pregnancy-associated changes in plasma concentration of the endocrine disruptor di(2-ethylhexyl) phthalate in a sheep model. Theriogenology. 2010; 73:141-146. [PubMed: 19828186]

159. Li D, Fareh S, Leung TK, Nattel S. Promotion of atrial fibrillation by heart failure in dogs: atrial remodeling of a different sort. Circulation. 1999; 100:87-95. [PubMed: 10393686]

160. Ellison KE, Stevenson WG, Sweeney MO, Epstein LM, Maisel WH. Management of arrhythmias in heart failure. Congest Heart Fail. 2003; 9:91-99. [PubMed: 12671340]

161. Maisel WH, Stevenson LW. Atrial fibrillation in heart failure: epidemiology, pathophysiology, and rationale for therapy. Am J Cardiol. 2003; 91:2D-8D.

162. Pogwizd SM, Bers DM. Cellular basis of triggered arrhythmias in heart failure. Trends Cardiovasc Med. 2004; 14:61-66. [PubMed: 15030791]

163. Pogwizd SM, Schlotthauer K, Li L, Yuan W, Bers DM. Arrhythmogenesis and contractile dysfunction in heart failure: Roles of sodium-calcium exchange, inward rectifier potassium current, and residual beta-adrenergic responsiveness. Circ Res. 2001; 88:1159-1167. [PubMed: 11397782]

164. Baicu CF, Zile MR, Aurigemma GP, Gaasch WH. Left ventricular systolic performance, function, and contractility in patients with diastolic heart failure. Circulation. 2005; 111:2306-2312. [PubMed: 15851588]

165. Dean JW, Lab MJ. Arrhythmia in heart failure: role of mechanically induced changes in electrophysiology. Lancet. 1989; 1:1309-1312. [PubMed: 2566835]

166. Col JJ, Weinberg SL. The incidence and mortality of intraventricular conduction defects in acute myocardial infarction. Am J Cardiol. 1972; 29:344-350. [PubMed: 5060806]

167. Nattel S, Maguy A, Le Bouter S, Yeh YH. Arrhythmogenic ion-channel remodeling in the heart: heart failure, myocardial infarction, and atrial fibrillation. Physiol Rev. 2007; 87:425-456. [PubMed: 17429037]

168. Biernacka A, Frangogiannis NG. Aging and Cardiac Fibrosis. Aging Dis. 2011; 2:158-173. [PubMed: 21837283]

169. De Jong S, van Veen TAB, van Rijen HVM, de Bakker JMT. Fibrosis and cardiac arrhythmias. J Cardiovasc Pharmacol. 2011; 57:630-8. [PubMed: 21150449]

170. Spach MS. Mounting evidence that fibrosis generates a major mechanism for atrial fibrillation. Circ Res. 2007; 101:743-5. [PubMed: 17932329]

171. Rudy Y, et al. Systems approach to understanding electromechanical activity in the human heart: a national heart, lung, and blood institute workshop summary. Circulation. 2008; 118:1202-1211. [PubMed: 18779456]

172. Loiselle DS, Gibbs CL. Species differences in cardiac energetics. Am J Physiol. 1979; 237:H908. [PubMed: 464076]

173. Harding SE. Human stem cell-derived cardiomyocytes for pharmacological and toxicological modeling. Ann N Y Acad Sci. 2011; 1245:48-49. [PubMed: 22211978]

174. Zeevi-Levin N, Itskovitz-Eldor J, Binah O. Cardiomyocytes derived from human pluripotent stem cells for drug screening. Pharmacol Ther. 2012; 134:180-188. [PubMed: 22269465]

175. Itzhaki I, et al. Calcium handling in human induced pluripotent stem cell derived cardiomyocytes. PLoS One. 2011; 6:e18037. [PubMed: 21483779]

176. Guo L, et al. Estimating the risk of drug-induced proarrhythmia using human induced pluripotent stem cell-derived cardiomyocytes. Toxicol Sci. 2011; 123:281-289. [PubMed: 21693436] 
177. Caspi O, et al. In vitro electrophysiological drug testing using human embryonic stem cell derived cardiomyocytes. Stem Cells Dev. 2009; 18:161-172. [PubMed: 18510453]

178. Braam SR, Mummery CL. Human stem cell models for predictive cardiac safety pharmacology. Stem Cell Res. 2010; 4:155-156. [PubMed: 20493455]

179. Posnack N, et al. The effect of endocrine-disrupting chemicals on human stem cell-derived cardiomyocytes. in. Soc Toxicol. 2014

180. Van Vliet EDS, Reitano EM, Chhabra JS, Bergen GP, Whyatt RM. A review of alternatives to di (2-ethylhexyl) phthalate-containing medical devices in the neonatal intensive care unit. J Perinatol. 2011; 31:551-60. [PubMed: 21311501]

181. Rosenmai AK, et al. Are Structural Analogues to Bisphenol A Safe Alternatives? Toxicol Sci. 201410.1093/toxsci/kfu030

182. Simmchen J, Ventura R, Segura J. Progress in the removal of di-[2-ethylhexyl]-phthalate as plasticizer in blood bags. Transfus Med Rev. 2012; 26:27-37. [PubMed: 21820855]

183. Mathapati S, Verma RS, Cherian KM, Guhathakurta S. Inflammatory responses of tissueengineered xenografts in a clinical scenario. Interact Cardiovasc Thorac Surg. 201010.1510/icvts. 2010.256719

184. Scientific Committee on Emerging and Newly Identified Health Risks. Opinion on the safety of medical devices containing DEHP-plasticized PVC or other plasticizers on neonates and other groups possibly at risk. 2008

185. Genay S, et al. Experimental study on infusion devices containing polyvinyl chloride: to what extent are they di(2-ethylhexyl)phthalate-free? Int J Pharm. 2011; 412:47-51. [PubMed: 21497186]

186. Cooper JE, Kendig EL, Belcher SM. Assessment of bisphenol A released from reusable plastic, aluminium and stainless steel water bottles. Chemosphere. 2011; 85:943-7. [PubMed: 21741673] 


\begin{tabular}{|c|c|c|c|c|c|c|c|c|c|c|c|c|c|c|c|c|c|}
\hline 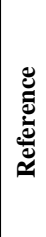 & $\begin{array}{l}\frac{m}{5} \\
\text { ì } \\
\dot{\sigma} \\
\overrightarrow{0} \\
-1\end{array}$ & 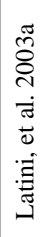 & 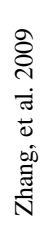 & 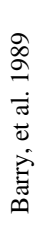 & 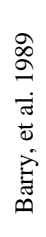 & 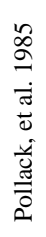 & 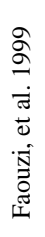 & 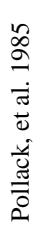 & 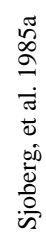 & 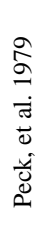 & 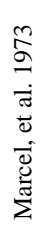 & 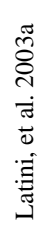 & 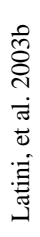 & 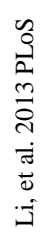 & 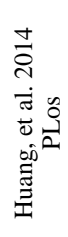 & 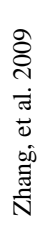 & 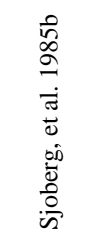 \\
\hline 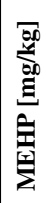 & & & & $\begin{array}{c}\infty \\
1 \\
\sim \\
\end{array}$ & $\begin{array}{l}\infty \\
\infty \\
\frac{\infty}{1} \\
\stackrel{1}{n} \\
\tilde{0}\end{array}$ & & & & 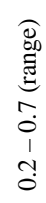 & & & & & & & & 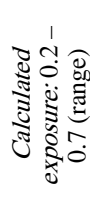 \\
\hline
\end{tabular}

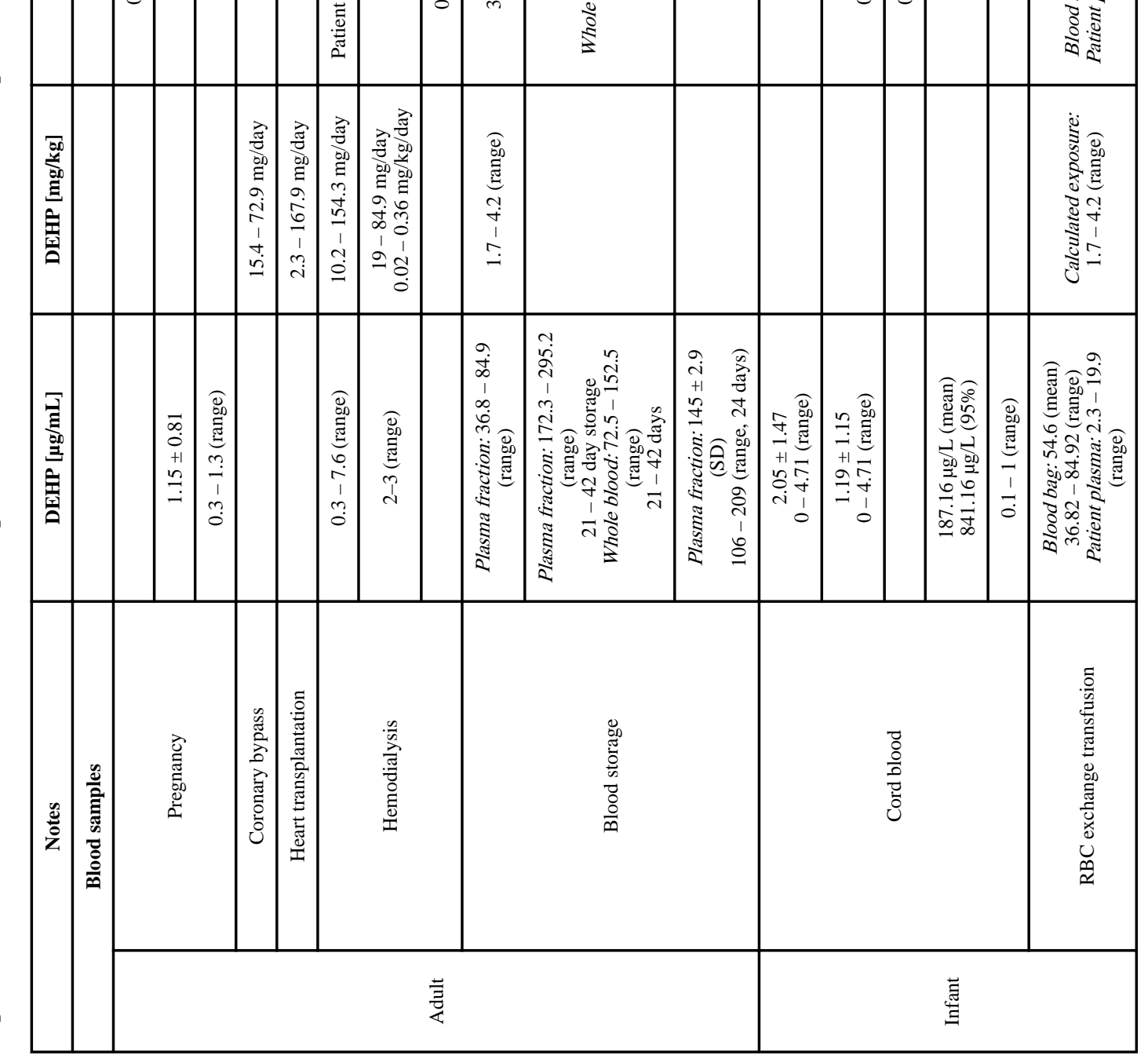




\begin{tabular}{|c|c|c|c|c|c|c|c|c|c|c|c|c|c|c|c|}
\hline 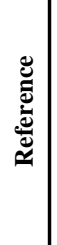 & 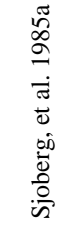 & 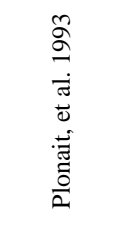 & 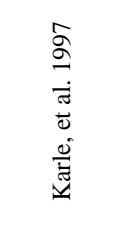 & 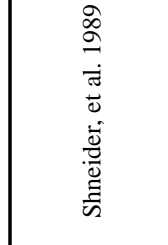 & 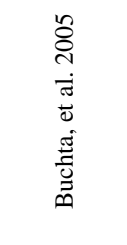 & & 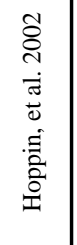 & 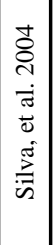 & 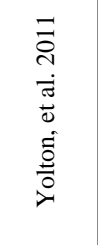 & 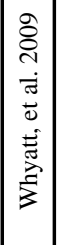 & 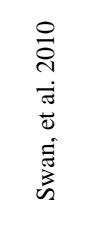 & 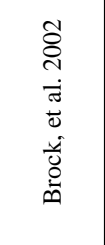 & 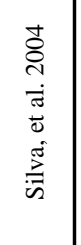 & 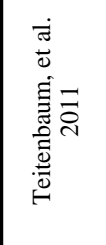 & 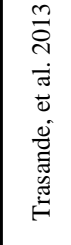 \\
\hline 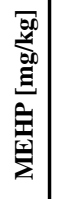 & 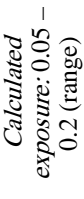 & & & & & & & & & & & & & & \\
\hline 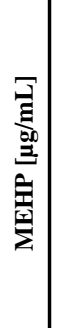 & 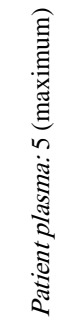 & & & & & & 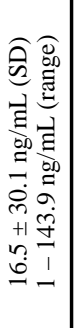 & 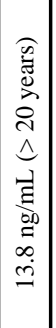 & 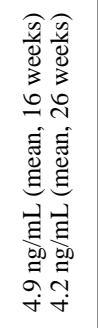 & 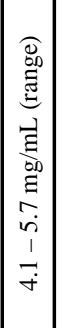 & 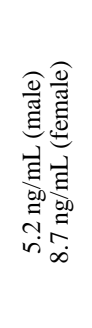 & 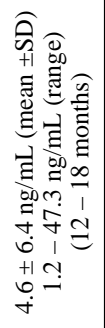 & 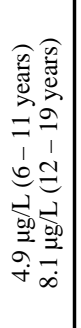 & 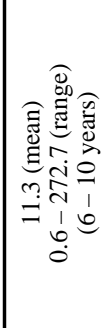 & \\
\hline 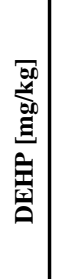 & 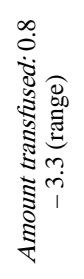 & 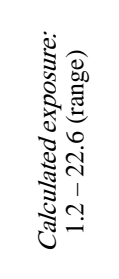 & 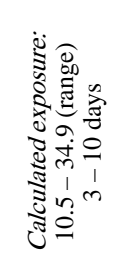 & 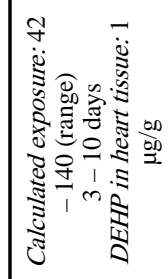 & 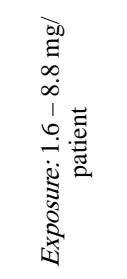 & & & & & & & & & & \\
\hline 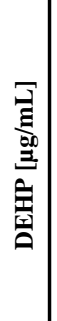 & 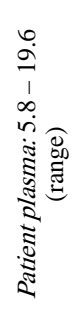 & 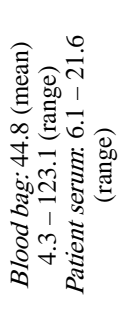 & 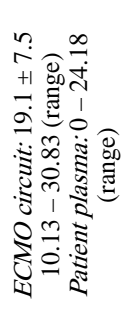 & 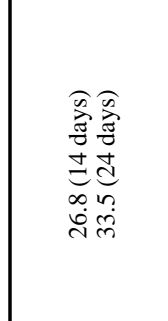 & 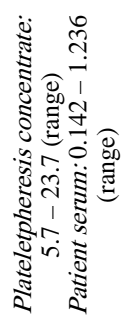 & & & & 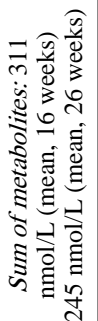 & & 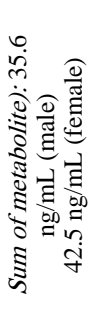 & & & & 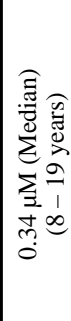 \\
\hline $\begin{array}{l}\mathscr{y} \\
\text { z }\end{array}$ & & & & 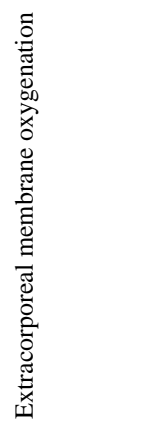 & 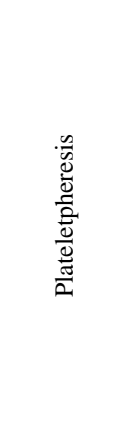 & 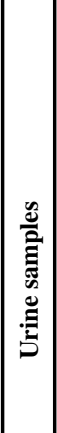 & 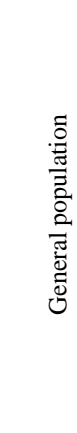 & & & 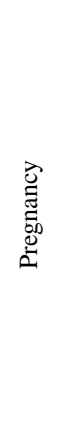 & & & & 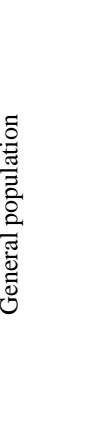 & \\
\hline & & & & & & & & & $\frac{\vec{z}}{\frac{z}{4}}$ & & & & ह & 恣 & \\
\hline
\end{tabular}




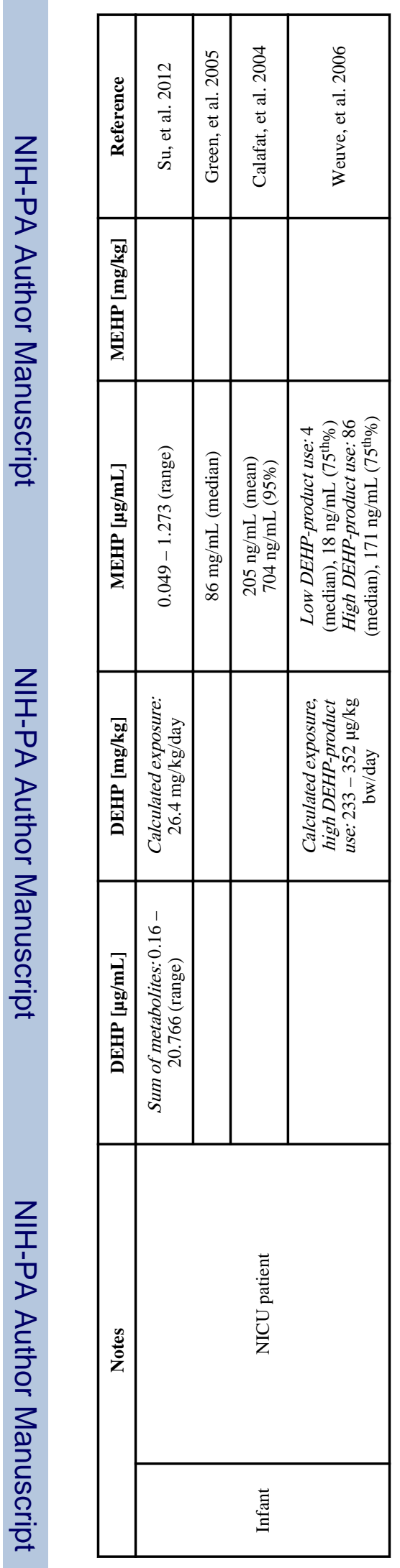

Cardiovasc Toxicol. Author manuscript; available in PMC 2015 December 01. 
Table 2

Experimental studies examining the effect of DEHP or MEHP on cardiac physiology.

\begin{tabular}{|c|c|c|c|}
\hline Reference & Concentration & $\begin{array}{l}\text { Model \& Approximate } \\
\text { Exposure Length }\end{array}$ & Result \\
\hline $\begin{array}{l}\text { Aronson, et al. } \\
1978\end{array}$ & $250 \mu \mathrm{M}$ DEHP & Excised rat heart; $60 \mathrm{~min}$ & $\begin{array}{l}\text { DEHP } \downarrow \text { heart rate, } \downarrow \text { coronary flow, } \downarrow \text { systolic tension } \\
\text { and } \uparrow \text { diastolic tension, prolonged PR and QT } \\
\text { intervals. DEHP } \uparrow \text { lactate levels in tissue and perfusate } \\
\text { media. }\end{array}$ \\
\hline $\begin{array}{l}\text { Barry, et al. } 1989, \\
1990\end{array}$ & $15-300 \mu \mathrm{g} / \mathrm{mL}$ MEHP & $\begin{array}{l}\text { Human atrial trabeculae; } 10 \\
-120 \mathrm{~min}\end{array}$ & $\begin{array}{l}\text { MEHP reversibly } \downarrow \text { contractility }\left(\mathrm{IC}_{50}=85 \mu \mathrm{g} / \mathrm{mL} \text { ) }\right. \\
\text { and } \uparrow \text { arrhythmia incidence. MEHP may act via } \\
\text { cholinergic receptors (atropine shifts } \mathrm{IC}_{50}=120 \mu \mathrm{g} / \\
\mathrm{mL} \text { ). }\end{array}$ \\
\hline Calley, et al. 1966 & $350 \mathrm{mg} / \mathrm{kg}$ DEHP & Rabbit; 3 min & DEHP $\downarrow$ blood pressure \\
\hline Gillum, et al. 2009 & $1-50 \mu \mathrm{g} / \mathrm{mL}$ DEHP & $\begin{array}{l}\text { Neonatal rat } \\
\text { cardiomyocytes; } 24-72 \\
\text { hours }\end{array}$ & $\begin{array}{l}\text { DEHP } \downarrow \text { conduction velocity, } \downarrow \text { cell synchronicity, } \downarrow \\
\text { gap-junctional connexin- } 43 \text { expression, and modified } \\
\text { mechanical movement of cell layers }\end{array}$ \\
\hline $\begin{array}{l}\text { Mangala, et al. } \\
2013\end{array}$ & $0-100 \mathrm{mg} / \mathrm{kg} /$ day & Female rat; 21 days & $\begin{array}{l}\text { Postnatal DEHP exposure (via lactation) impaired } \\
\text { insulin signal transduction and glucose oxidation in } \\
\text { cardiac muscle in female progeny. }\end{array}$ \\
\hline $\begin{array}{l}\text { Martinez-Arguelles, } \\
\text { et al. } 2012\end{array}$ & $300 \mathrm{mg} / \mathrm{kg} /$ day DEHP & Male rat; 7 days & $\begin{array}{l}\text { Prenatal DEHP exposure } \downarrow \text { heart rate, } \downarrow \text { systolic \& } \\
\text { diastolic blood pressure in adult males. }\end{array}$ \\
\hline Posnack, et al. 2012 & $50-100 \mu \mathrm{g} / \mathrm{mL}$ DEHP & $\begin{array}{l}\text { Neonatal rat } \\
\text { cardiomyocytes; } 72 \text { hours }\end{array}$ & $\begin{array}{l}\text { DEHP } \uparrow \text { fatty acid substrate utilization, } \uparrow \text { oxygen } \\
\text { consumption, } \uparrow \text { mitochondrial mass, } \uparrow \text { PPARa } \\
\text { expression and } \uparrow \text { extracellular acidosis. Effects } \\
\text { partially mimicked by PPARa agonist. }\end{array}$ \\
\hline Posnack, et al. 2011 & $1-50 \mu \mathrm{g} / \mathrm{mL}$ DEHP & $\begin{array}{l}\text { Neonatal rat } \\
\text { cardiomyocytes; } 24-72 \\
\text { hours }\end{array}$ & $\begin{array}{l}\text { DEHP modified gene expression related to cell } \\
\text { electrical activity, calcium handling, adhesion and } \\
\text { microtubular transport. DEHP also modified adhesion } \\
\text { and transport proteins. }\end{array}$ \\
\hline Rock, et al. 1987 & $0-100 \mathrm{mg}$ MEHP & Rat $;<15 \min$ & $\begin{array}{l}\text { MEHP } \downarrow \text { heart rate }(\mathrm{LOAEL}=10 \mathrm{mg} \text { ) and } \downarrow \text { blood } \\
\text { pressure (LOAEL }=55 \mathrm{mg} \text { ). }\end{array}$ \\
\hline Rubin, et al. 1973 & $4 \mu \mathrm{g} / \mathrm{mL}$ DEHP & $\begin{array}{l}\text { Chick embryonic heart } \\
\text { cells; } 30 \text { min }-24 \text { hour }\end{array}$ & $\begin{array}{l}\text { DEHP stopped cell contractions ( } 30 \mathrm{~min} \text { ), and resulted } \\
\text { in } 97-98 \% \text { cell death within } 24 \text { hours. }\end{array}$ \\
\hline $\begin{array}{l}\text { Schulpen, et al. } \\
2013\end{array}$ & $0.004-4.4 \mathrm{mM}$ MEHP & $\begin{array}{l}\text { Embryonic stem cells; } 5 \text { - } 7 \\
\text { days }\end{array}$ & $\begin{array}{l}\text { MEHP } \downarrow \text { cell viability and cardiac differentiation, and } \\
\text { genes associated with these endpoints. }\end{array}$ \\
\hline Wei, et al. 2012 & $0.25-6.25 \mathrm{mg} / \mathrm{kg} / \mathrm{day}$ DEHP & Rat; 40 days & $\begin{array}{l}\text { Prenatal and postnatal DEHP exposure } \downarrow \text { renal protein } \\
\text { expression, } \uparrow \text { blood pressure }\end{array}$ \\
\hline
\end{tabular}


Table 3

Epidemiological studies examining the association between higher urinary concentrations of DEHP metabolites and cardiovascular disease.

\begin{tabular}{|l|l|}
\hline Reference & Result \\
\hline Lind, et al. 2011 & $\begin{array}{l}\text { Cross-sectional analysis of PIVUS data. Higher serum MEHP concentration was associated with echolucent intima- } \\
\text { media complex and overt plaques. 4.53 ng/mL serum MEHP (mean) }\end{array}$ \\
\hline Olsen, et al. 2012 & $\begin{array}{l}\text { Cross-sectional analysis of PIVUS data. Higher serum MEHP concentration was associated with LDL cholesterol } \\
\text { levels, but not associated with deviations in blood pressure. The effect on cholesterol levels was not significant after } \\
\text { multiple-testing correction. }\end{array}$ \\
\hline Transande, et al. 2013 & $\begin{array}{l}\text { Cross-sectional analysis of NHANES survey data. Higher urinary concentration of DEHP metabolites associated with } \\
\text { increased blood pressure in children aged 6-19 years old. Median urinary DEHP metabolite molar concentration: } \\
0.337\end{array}$ \\
\hline
\end{tabular}


Table 4

Experimental studies which measured BPA exposure in humans via blood or urine samples.

\begin{tabular}{|c|c|c|c|}
\hline & Notes & BPA $[\mathrm{ng} / \mathrm{mL}$, mean $\pm \mathrm{SEM}]$ & Reference \\
\hline \multicolumn{2}{|r|}{ Blood samples } & & \\
\hline \multirow{11}{*}{ Adult } & \multirow{2}{*}{ General population } & $\begin{array}{c}3.83 \pm 1.98(\mathrm{SD}) \\
1.30-8.17(\text { range })\end{array}$ & Aris, A. 2013 \\
\hline & & $\begin{array}{c}0.2 \pm 0.18(\mathrm{SD}) \\
0.1-2.27 \text { (range) }\end{array}$ & Zhang, et al. 2013 \\
\hline & \multirow{5}{*}{ Pregnancy } & $\begin{array}{c}5.9 \pm 0.94 \\
\mathrm{ND}-22.3 \text { (range) }\end{array}$ & Padmanabhan, et al. 2008 \\
\hline & & $\begin{array}{c}4.4 \pm 3.9 \\
0.3-18.9 \text { (range) }\end{array}$ & Schonfelder, et al. 2002 \\
\hline & & $\begin{array}{c}9.04 \pm 0.81 \\
\mathrm{ND}-66.48 \text { (range) }\end{array}$ & Lee, et al. 2008 \\
\hline & & $\begin{array}{c}1.36 \pm 1.18(\mathrm{SD}) \\
\mathrm{ND}-4.46(\text { range })\end{array}$ & Aris, A. 2013 \\
\hline & & $\begin{array}{l}3.58 \pm 4.27(\mathrm{SD}) \\
0.10-29(\text { range })\end{array}$ & Zhang, et al. 2013 \\
\hline & \multirow{3}{*}{ Hemodialysis } & $10 \pm 6.6$ (maintanence dialysis) & Krieter, et al. 2012 \\
\hline & & $0-15.5$ & Sajiki, et al. 2008 \\
\hline & & $5.3 \pm 0.3$ & Kanno, et al. 2007 \\
\hline & Endometriotic patients & $\begin{array}{c}2.91 \pm 1.74 \\
0-7.12 \text { (range) }\end{array}$ & Cobellis, et al. 2009 \\
\hline Children & General population & $\begin{array}{c}3.18 \pm 1.66(\mathrm{SD}) \\
1.20-8.76(\text { range }) \\
(1-5 \text { years })\end{array}$ & Zhang, et al. 2013 \\
\hline \multirow{4}{*}{ Infant } & \multirow{4}{*}{ Cord blood } & $\begin{array}{c}2.9 \pm 2.5 \\
0.2-9.2 \text { (range) }\end{array}$ & Schonfelder, et al. 2002 \\
\hline & & $\begin{array}{c}1.13 \pm 0.08 \\
\mathrm{ND}-8.86 \text { (range) }\end{array}$ & Lee, et al. 2008 \\
\hline & & $\begin{array}{c}1.23 \pm 1.04(\mathrm{SD}) \\
\mathrm{ND}-4.60(\text { range })\end{array}$ & Aris, A. 2013 \\
\hline & & $\begin{array}{c}0.13 \pm 0.12(\mathrm{SD}) \\
0.1-0.79 \text { (range) }\end{array}$ & Zhang, et al. 2013 \\
\hline \multicolumn{2}{|r|}{ Urine samples } & & \\
\hline \multirow{10}{*}{ Adult } & \multirow{8}{*}{ General population } & 1.15 mean & Bushnik, et al. 2010 \\
\hline & & 2.4 mean & Calafat, et al. 2008 \\
\hline & & 1.5 mean & Mendiola, et al. 2010 \\
\hline & & ND - 42 & Genuis, et al. 2012 \\
\hline & & 2.61 & Heffernan, et al. 2013 \\
\hline & & 2.61 mean & Heffernan, et al. 2013 \\
\hline & & $0.5-15.5$ & Calafat, et al. 2008 \\
\hline & & $\begin{array}{c}1.90 \pm 1.23(\mathrm{SD}) \\
0.10-8.70(\text { range })\end{array}$ & Zhang, et al. 2013 \\
\hline & Industrial worker & $\begin{array}{c}55.73 \pm 5.48 \text { (SD) } \\
5.56-1934.85 \text { (range) }\end{array}$ & Wang, et al. 2012 \\
\hline & Pregnancy & 1,250 (single patient) & Sathyanarayana, et al. 2011 \\
\hline
\end{tabular}




\begin{tabular}{|c|c|c|c|}
\hline \multicolumn{2}{|r|}{ Notes } & BPA $[\mathrm{ng} / \mathrm{mL}$, mean \pm SEM $]$ & Reference \\
\hline & & $\begin{array}{l}70 \text { (mean), pre-term birth } \\
30 \text { (mean), normal gestation time }\end{array}$ & Patel, et al. 2013 \\
\hline \multirow{6}{*}{ Children } & \multirow{6}{*}{ General population } & $\begin{array}{c}2.98 \\
0.65-265 \text { (range) } \\
(0-5 \text { years })\end{array}$ & Heffernan, et al. 2013 \\
\hline & & $\begin{array}{c}3.9 \text { (1 year), } 2.9 \text { ( } 2 \text { year }), 2.9 \text { (3 year) } \\
0.4-616 \text { (range) }\end{array}$ & Braun, et al. 2011 \\
\hline & & $\begin{array}{l}8.9 \pm 23.6(\mathrm{SD}) \\
0.4-211(\text { range }) \\
(2-5 \text { years })\end{array}$ & Morgan, et al. 2011 \\
\hline & & $\begin{array}{l}2.7 \text { (mean) } \\
(3-14 \text { years })\end{array}$ & Becker, et al. 2009 \\
\hline & & $\begin{array}{c}3.6 \text { (mean) } \\
0.3-40 \text { (range) } \\
(6-10 \text { years })\end{array}$ & Teitelbaum, et al. 2008 \\
\hline & & $\begin{array}{l}3.6(\text { mean })(6-11 \text { years }) \\
3.7 \text { (mean })(12-19 \text { years }) \\
0.4-149 \text { (range, all ages })\end{array}$ & Calafat, et al. 2008 \\
\hline \multirow{3}{*}{ Infant } & General population & $0-17.85$ & Volkel, et al. 2011 \\
\hline & \multirow[b]{2}{*}{ NICU patient } & $\begin{array}{l}\text { Total BPA } 30.3 \pm 4.8(\mathrm{SD}) ; 1.6-946 \text { (range) } \\
\text { Free BPA: } 1.8 \pm 3.2 ; \mathrm{ND}-17.3 \text { (range) } \\
\text { Calculated max exposure: } 35.95 \text { ug/kg/day }\end{array}$ & Calafat, et al. 2009 \\
\hline & & $\begin{array}{c}2-196 \text { (range) } \\
\text { High medical device use: } 18.5 \text { (median), } 47.3\left(75^{\text {th } \%)}\right. \\
\text { Low medical device use: } 13.2 \text { (median), } 38.2\left(75^{\text {th } \%)}\right. \\
\text { Calculated max exposure: } 7.45 \mu \mathrm{g} / \mathrm{kg} / \mathrm{day}\end{array}$ & Duty, et al. 2013 \\
\hline
\end{tabular}


Table 5

Experimental studies examining the effect of BPA on cardiac physiology.

\begin{tabular}{|c|c|c|c|}
\hline Reference & Concentration & Model \& Exposure Length & Results \\
\hline Asano, et al. 2010 & $10-100 \mu \mathrm{M}$ & $\begin{array}{l}\text { Human \& canine coronary } \\
\text { smooth muscle cells; } 1 \text { min }\end{array}$ & BPA activates maxi-K channels \\
\hline Belcher, et al. 2011 & $1 \mathrm{pM}-1 \mathrm{nM}$ & $\begin{array}{l}\text { Female ventricular myocyte; } 7 \\
\text { min }\end{array}$ & $\begin{array}{l}\text { BPA } \uparrow \text { contractility. Effect abolished in myocytes } \\
\text { from ovariectomized females, and ER } \beta \text { knockout } \\
\text { mice. Effect not inhibited by L-Name pretreatment. }\end{array}$ \\
\hline $\begin{array}{l}\text { Deutschmann, et al. } \\
2013\end{array}$ & $1 \mu \mathrm{M}-1 \mathrm{mM}$ & $\begin{array}{l}\text { Mouse cardiomyocytes \& } \\
\text { dorsal root ganglion neurons, } \\
\text { rat endocrine GH3 cells, } \\
\text { human HEK cells; } 1 \text { min }\end{array}$ & $\begin{array}{l}\text { BPA reversibly blocks multiple calcium channels. } \\
\text { Effect not due to intracellular signaling (PKA, PKC } \\
\text { pathways). } \mathrm{EC}_{50}=26-35 \mu \mathrm{M}\end{array}$ \\
\hline Gao, et al. 2013 & $1 \mathrm{nM}$ & $\begin{array}{l}\text { Female ventricular myocyte; } \\
15 \text { min }\end{array}$ & $\begin{array}{l}\text { BPA transiently alters ryanodine receptor } \\
\text { phosphorylation at PKA site and phospholamban at } \\
\text { CAMKII site. Effects abolished with ER } \beta \text { or PKA } \\
\text { blocker. }\end{array}$ \\
\hline Lee, et al. 2012 & $1-100 \mathrm{ng} / \mathrm{mL}$ & Rice fish embryo; $2-4$ days & $\mathrm{BPA} \downarrow$ heart rate \\
\hline O'Reilly, et al. 2012 & $0.1-1 \mathrm{mM}$ & HEK cells; 2 min & $\begin{array}{l}\text { BPA blocks hNav1.5 sodium channel in closed/ } \\
\text { resting-state. NOAEL }=100 \mathrm{nM}, \mathrm{LOAEL}=1 \mu \mathrm{M} \text {, } \\
\mathrm{K}_{\mathrm{d}}=25 \mu \mathrm{M}\end{array}$ \\
\hline Pant, et al. 2011 & $0.1-100 \mu \mathrm{M}$ & Rat right atria; $10 \mathrm{~min}$ & $\begin{array}{l}\text { BPA } \downarrow \text { heart rate, } \downarrow \text { force of contraction. Effect } \\
\text { abolished with L-Name pretreatment or methylene } \\
\text { blue. Effect not inhibited by atropine pretreatment. }\end{array}$ \\
\hline Pant, et al. 2012b & $\begin{array}{l}\mathrm{LD}_{50}=841 \mathrm{mg} / \mathrm{kg} \text { bw } \\
\text { (i.p.), } 35 \mathrm{mg} / \mathrm{kg} \text { bw (i.v.). }\end{array}$ & Female rat; 7 min & $\begin{array}{l}\text { Lethal BPA dose }(40 \mathrm{mg} / \mathrm{kg} \text { bw) produced } \\
\text { respiratory arrest, hypotension and bradycardia. }\end{array}$ \\
\hline \multirow[t]{2}{*}{ Patel, et al. 2013} & $0.5-200 \mu \mathrm{g} / \mathrm{kg} /$ day & $\begin{array}{l}\text { Male mice; } 30 \text { days }-4 \\
\text { months }\end{array}$ & $\begin{array}{l}\text { Prenatal and postnatal BPA exposure resulted in } \\
\text { concentric remodeling, } \uparrow \text { velocity circumferential } \\
\text { shortening, } \uparrow \text { ascending aorta velocity, and } \uparrow \\
\text { calcium mobility }\end{array}$ \\
\hline & $0.5-200 \mu \mathrm{g} / \mathrm{kg} / \mathrm{day}$ & $\begin{array}{l}\text { Female mice; } 30 \text { days }-4 \\
\text { months }\end{array}$ & $\begin{array}{l}\text { Prenatal and postnatal BPA } \downarrow \text { LV mass and wall } \\
\text { thickness, } \uparrow \text { blood pressure, } \downarrow \text { calcium mobility }\end{array}$ \\
\hline Posnack, et al. 2014 & $0.1-100 \mu \mathrm{M}$ & $\begin{array}{l}\text { Female excised whole heart; } \\
15 \text { min }\end{array}$ & $\begin{array}{l}\text { BPA } \downarrow \text { epicardial conduction velocity, } \uparrow \\
\text { atrioventricular delay, } \uparrow \text { PR segment time, } \uparrow \text { action } \\
\text { potential duration, heart block at high doses }\end{array}$ \\
\hline Schirling, et al. 2006 & $50-100 \mu \mathrm{g} / \mathrm{L}$ & Snail embryo; 9 days & $\mathrm{BPA} \downarrow$ heart rate \\
\hline \multirow{2}{*}{ Yan, et al. 2013} & $1 \mathrm{nM}$ & $\begin{array}{l}\text { Female excised whole heart; } \\
60 \mathrm{~min}\end{array}$ & $\begin{array}{l}\text { BPA } \uparrow \text { arrhythmia duration (ischemia reperfusion } \\
\text { model). Effects abolished with ERa }+E R \beta \text { blocker }\end{array}$ \\
\hline & $1 \mathrm{nM}$ & $\begin{array}{l}\text { Female ventricular myocyte; } 2 \\
\text { hour }\end{array}$ & $\mathrm{BPA} \uparrow$ spontaneous after contractions \\
\hline Yan, et al. 2011 & $1 \mathrm{nM}$ & $\begin{array}{l}\text { Female ventricular myocyte; } 7 \\
\text { min }\end{array}$ & $\begin{array}{l}\text { BPA } \uparrow \text { spontaneous after contractions, } \uparrow \text { calcium } \\
\text { leak and load in sarcoplasmic reticulum. Effects } \\
\text { abolished in ER } \beta \text { knockout mice }\end{array}$ \\
\hline
\end{tabular}




\section{Table 6}

Epidemiological studies examining the association between higher urinary concentrations of BPA and cardiovascular disease.

\begin{tabular}{|c|c|}
\hline Reference & Result \\
\hline Bae, et al. 2012 & $\begin{array}{l}\text { Higher urinary BPA concentration was associated with increased blood pressure and decreased heart rate } \\
\text { variability. Mean urinary BPA: } 1.2 \mu \mathrm{g} / \mathrm{g} \text { creatinine }\end{array}$ \\
\hline Khalil, et al. 2014 & Higher urinary BPA concentration was associated with increased blood pressure in male children. \\
\hline LaKind, et al. 2012 & $\begin{array}{l}\text { Cross-sectional analysis of NHANES survey data. Higher urinary BPA concentrations not associated with } \\
\text { cardiovascular disease. }\end{array}$ \\
\hline Lang, et al. 2008 & $\begin{array}{l}\text { Cross-sectional analysis of NHANES survey data. Higher urinary BPA concentrations associated with } \\
\text { cardiovascular disease. } 4.53 \mathrm{ng} / \mathrm{mL} \text { (mean, males), } 4.66 \mathrm{ng} / \mathrm{mL} \text { (mean, females), } 8 \mathrm{ng} / \mathrm{mL} \text { (mean, reported } \\
\text { cardiovascular disease). }\end{array}$ \\
\hline Lind, et al. 2011 & $\begin{array}{l}\text { Cross-sectional analysis PIVUS study. Higher serum BPA concentration was associated with increased } \\
\text { echogenicity of the intima-media complex and overt plaques. } 3.76 \mathrm{ng} / \mathrm{mL} \text { serum BPA (mean) }\end{array}$ \\
\hline Melzer, et al. 2012a & $\begin{array}{l}\text { Higher urinary BPA concentration was associated with severe coronary artery disease. } 1.28 \mathrm{ng} / \mathrm{mL} \text { (median) - } \\
\text { normal arteries; } 1.53 \mathrm{ng} / \mathrm{mL} \text { (median) - severe coronary artery disease }\end{array}$ \\
\hline Melzer, et al. 2012b & $\begin{array}{l}\text { Longitudinal study examined association between higher urinary BPA concentration and incidence of coronary } \\
\text { artery disease. } 1.24 \mathrm{ng} / \mathrm{mL} \text { (median)-normal; } 1.35 \mathrm{ng} / \mathrm{mL} \text { (median)-cases }\end{array}$ \\
\hline Melzer, et al. 2010 & $\begin{array}{l}\text { Cross-sectional analysis of NHANES survey data. Higher urinary BPA concentrations associated with } \\
\text { cardiovascular disease. } 1.79 \mathrm{ng} / \mathrm{mL} \text { urinary BPA (mean, all participants) }\end{array}$ \\
\hline Olsen, et al. 2012 & $\begin{array}{l}\text { Cross-sectional analysis of PIVUS data. Higher serum BPA concentration was associated with LDL and HDL } \\
\text { cholesterol levels, but not associated with deviations in blood pressure. The effect on cholesterol levels was not } \\
\text { significant after multiple-testing correction. }\end{array}$ \\
\hline Shankar \& Teppala. 2012 & $\begin{array}{l}\text { Cross-sectional analysis of NHANES survey data. Higher urinary BPA concentrations associated with increased } \\
\text { blood pressure. }\end{array}$ \\
\hline
\end{tabular}

